\title{
THE NEW
}

\section{PANAMA Canal COMPANY.}

I. FINAL AND DEFINITE REPORT OF THE INTERNATIONAL TECHNICAL COMMISSION, RENDERED NOVEMBER 16, 1898, AND DELIVERED TO THE PRESIDENT OF THE UNITED STATES, DECEMBER 2, 1898 .

II. ACTUAL PRESENT STATUS OF THE PANAMA CANAL AND WORKS.

III. ENTIRELY NEW MANAGEMENT AND FINANCIAL CONDITION OF THE REORGANIZED COMPANY.

IV. PERFECT CONCESSIONS AND LEGAL TITLES.

V. PROFILE AND MAP, SHOWINO LINE OF CANAL AND PARTS ALREADY CONSTRUCTED; PHOTOGRAPHIC VIEWS OF CANAL AND CONSTRUCTION WORK.

Dated, December 26, 1898. 




\section{THE NEW PANAMA CANAL CO.}

\section{EXECUTIVE OFFICERS.}

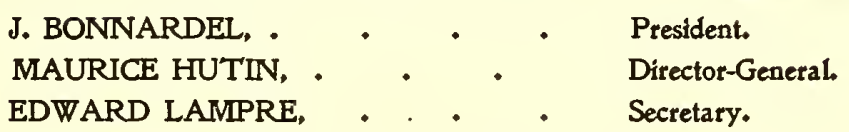

\section{BOARD OF DIRECTORS.}

Mr. Bonnardel, President,

Director of the Western Railroad Company of France.

Mr. Baillet,

Ex.Judge of the Commercial Court of Orleans.

Mr. BROLEMANN,

Director of the Credit Lyonnais, and also President

Mr. Chanove, of the Franco-Canadian Credit Foncier.

Managing Director of the Steel and Iron Works of Huta and Bankova, in Russia.

Mr. JONQUIËRE,

Inspector of Public Lands and Works, and Director

Mr. Lebègue, of the Realty Company of Lyons, France.

Director of the Bank Société Générale and Ex-Director of the Bank of France (Branch for Nancy).

Mr. MÉLIODON,

Director of the Comptoir National d'Escompte of

Mr. RameT, Paris and of The Credit Foncier of France.

Ex-President of the Commercial Court of Rennes, France.

Mr. De St. Quentin,

Director of the Credit Industrial Commercial.

Mr. SOUCHON,

Director of the Coal Mining Company of Saint Etienne.

COMIMERCIAL REPRESENTATIVE AT NEW YORK.

XAVIER BOYARD, 45 Wall Street, New York City.

GENERAL COUNSEL.

SULLIVAN \& CROMWELL,

United States Trust Co. Bldg.,

45 Wall St., New York City. 


\section{PHOTOGRAPHIC ILLUSTRATIONS.}

The illustrations were made from photographs (not merely drawings) of various sections of the work, taken the latter part of the year 1897 and in the year 1898 , and are intended to convey to the reader some idea of the present condition and progress of work on the Canal.

The plate showing a portion of the completed canal, with a boat in the foreground, illustrates the condition of the Canal for 14 miles from the Atlantic, inland. This portion of the Canal is navigable, as is also about 4 miles from the Pacific, inland.

The various cuts of the Culebra completely refute the charge that it was impossible to make a suitable excavation at this point.

The other illustrations show the progress of the work and the character of the plant employed in its execution. Most of this machinery and plant is of the most approved American design and manufacture.

\section{MAP AND PROFILE.}

The Profile shows the three Plans all equally feasible and about equal in cost, but differing in time required for execution. Level 20.75 has been adopted subjected to further reduction of the number of locks if found desirable in completion.

It also illustrates the large proportion of work already completed, and clearly indicates, by dotted lines, the original surface line (indicated in black) and the cutting down of the same to the present levels (indicated in red).

The Map shows the route of the Canal from ocean to ocean, and the line of the Panama Railroad, which is contiguous. 


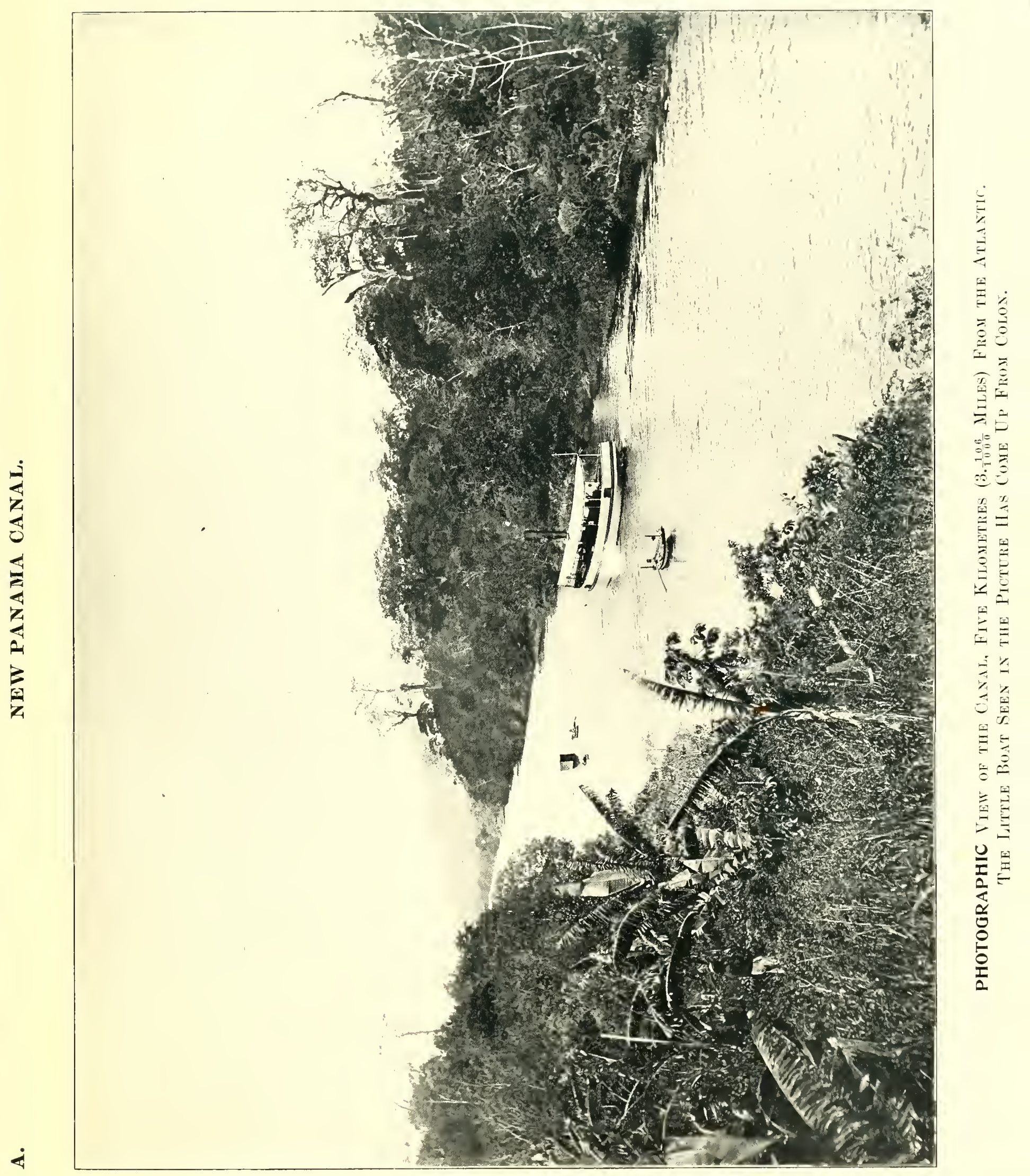




\section{INTERNATIONAL TECHNICAL COMIMISSION. \\ COMPOSED OF ENGINEERS OF UNITED STATES, FRANCE, RUSSIA, ENGLAND, GERMANY AND COLOMBIA.}

Mr. A. ROBAGLIA, General Inspector of Bridges and Roads (France) retired, President.

*Mr. BOUVIER, General Inspector of Bridges and Roads (France), retired, Secretary.

Brig.=Gen. HENRY L. ABBOT, Corps of Engineers, U. S. Army, retired.

Mr. E. CASTEL, General Inspector of Mines (France), retired.

Mr. V. DAYMARD, Chief Engineer of Transatlantique Co. (France).

Mr. FARGUE, General Inspector of Bridges and Roads (France), retired.

Mr. A. FTELEY, Chief Engineer, Aqueduct Commissioners, New York City, United States America.

Mr. FULSCHER, "Conseiller intime" at the Department of Public Works of Prussia, tormerly Engineering Director at the works of the Kiel Canal (Prussia).

Mr. HERSENT, Civil Engineer (France).

Mr. W. HENRY HUNTER, Chief Engineer of the Manchester Canal Co. (England).

Mr. KOCH, Councillor Department of Public Works, Director of the Technical Academy of Darmstadt, formerly Engineering Member of the Imperial Commission for the Kiel Canal (Prussia).

Mr. JULES MARTIN, Inspector General of Ponts et Chaussées, retired (France).

Mr. C. SKALKOWSKI, formerly Director of Mines for the Department of Agriculture and Lands (Russia).

* Mr. SOSA, Chief Engineer of Colombian States (South America).

* Recently deceased. 


-




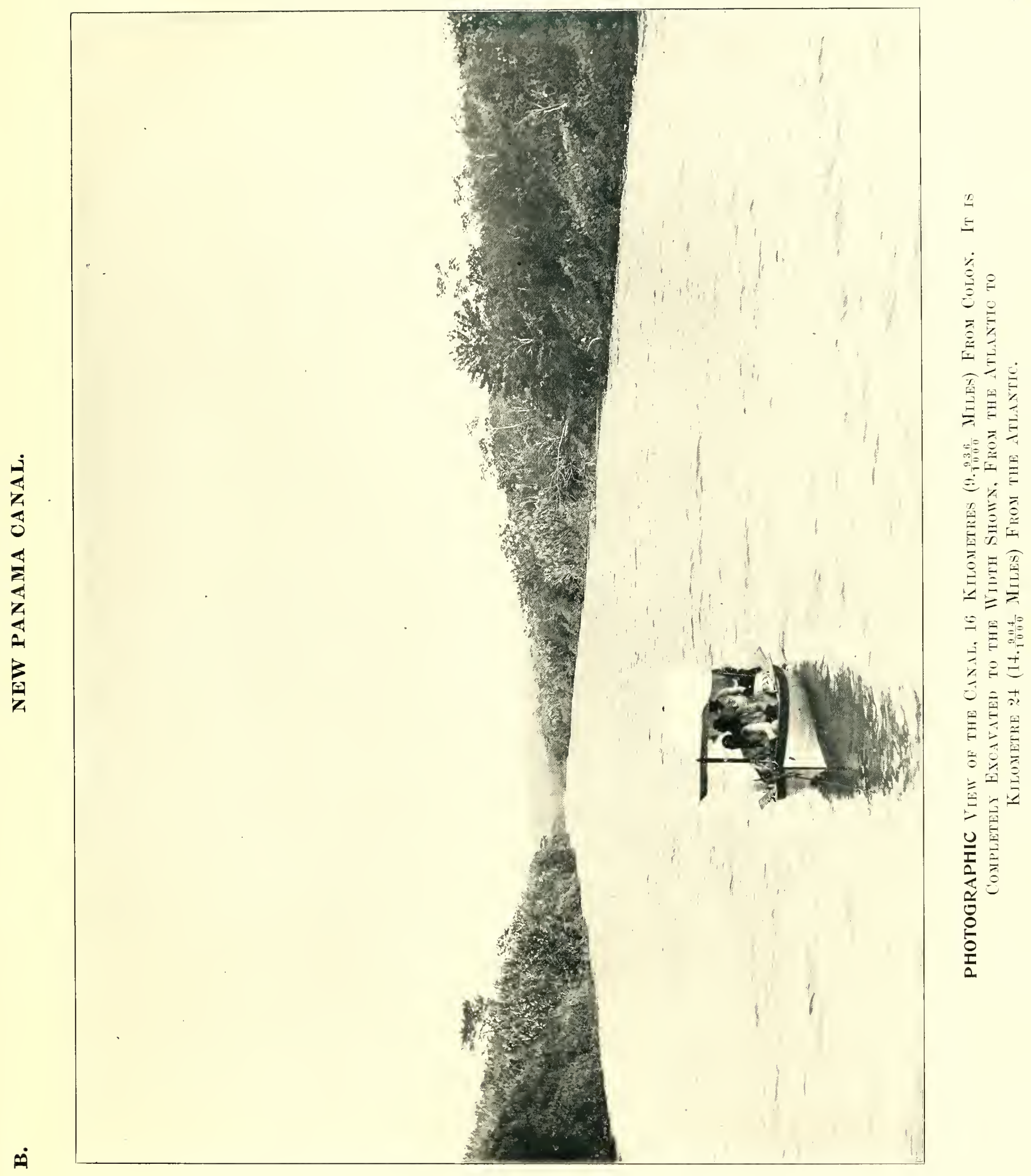




\section{BRIEF HISTORY OF THE PREDECESSOR COMPANY, THE OLD PANAMA CANAL COMPANY (THE UNIVERSAL INTEROCEANIC CANAL COM- PANY).}

1880-1888.

PReliminaRy OBSERVATIONS.

The wide-spread interest in the financial failure of the old Panama Company can be explained by the universal character of the undertaking, the celebrity of the man who was at its head, and the importance of the interests involved.

In France, this failure, unfortunately, served at the time certain political purposes; therefore public attention was diverted from the undertaking itself.

It must, however, be conceded that the construction of the interoceanic Canal is a commercial enterprise like any other. For its successful planning and execution every detail must first be carefully studied. The solution to be arrived at should not be based upon preconceived ideas, however attractive these may appear. Such a method is dangerous, especially so in an undertaking, which in its greatness, difficulties and complexity, has no precedent.

An impartial examination of the financial failure of the company founded by Mr. De Lesseps, discloses a number of causes which had more or less grave consequences, speaking either from a financial or technical point of view but all relate to an initial or fundamental cause, that is, from its beginning there was an omission to make carefui and thorough surveys to determine the character and cost of the work, as well as the time necessary to complete it. 
It would be unjust, however, to underestimate the importance of the work accomplished, and the results obtained, by the old Company. They will be fully presented later herein.

\section{The International Congress held at Paris in MAY, 1879.}

Notwithstanding its extreme interest, it is not possible even to summarize the history of the discoveries, explorations and plans of maritime canals on the American Isthmus, prior to the year 1879 , at which time an international Congress met in Paris and, after an examination of the several plans which had been presented, adopted the following conclusion:

"The Congress is of the opinion that the cutting of an international sea level Canal, so desirable in the interests of commerce and of navigation, is possible, and that this maritime canal, in order to provide the indispensable facility for access and use that a passage of this kind should offer, ought to be constructed from the Gulf of Limon (Colon) to the Bay of Panama."

The conclusion of the technical Commission of this Congress were slightly less formal, and were thus expressed :

"It is the opinion of the Technical Commission that the Interoceanic Canal should be constructed from the Gulf of Limon to the Bay of Panama, and this Commission specially recommends the building of a sea level Canal along this route."

Reference to the debates which took place in the Congress of 1879 discloses that although a great majority of its members recognized the superiority of the proposed plan (Colon-Panama) many among them, and not the least eminent and experienced, declare, that if the realization of the plan of a sea level canal was to be urged because it was most conducive to the great growth of traffic, as well as to 


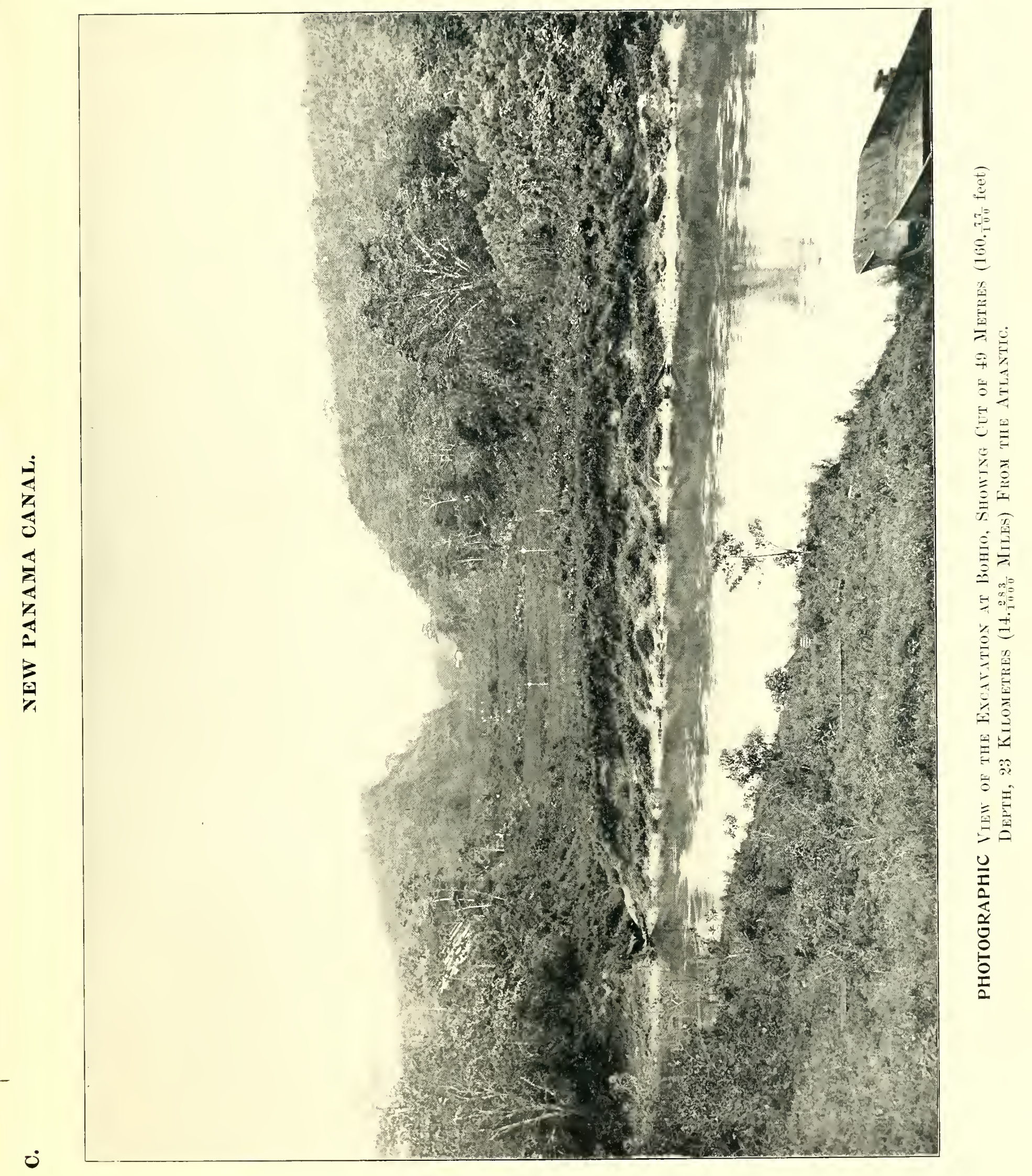



the safety and rapidity of its passage, it was to be feared that this would present too many difficulties, or too great a cost, and that a canal with locks would fully satisfy the wants of navigation.

No doubt the personal opinion of Mr. De Lesseps, the originator of the Suez sea level canal, had great weight in the decision of the Congress. Mr. De Lesseps had always asserted that the canal between the Atlantic and Pacific should be constructed at a constant level.

We are compelled to admit that the completed surveys and work accomplished in the Isthmus of Panama undeniably demonstrate that Mr. De Lesseps' ideal is now practically susceptible of realization; but Mr. De Lesseps was entirely mistaken concerning the conditions of exccution in the first attempt he made.

The Congress of 1879 had calculated that the time for the finishing of the Canal would be at least twelve years, and it fixed the probable expense of the undertaking at $\$ 2$ I 4,000,000. Supposing that the interest on capital during construction amounted $\$ 26,000,000$, there would be a total expenditure of $\$ 240,000,000$.

Mr. De Lesseps, in the beginning of the year I880, went to the Isthmus of Panama with a company of engineers for the purpose of completing the surveys which had been sub. mitted the preceding year to the International Congress. The estimate of the construction work proper authorized by this Commission amounted to $\$ 166,800,000$.

At the same time this Commission expressed the opinion that with good and judicious organization the work might be concluded in eight years. Mr. De Lesseps believed it to be possible to reduce this estimate of expenditures.

It was under these conditions that the work was commenced in $188 \mathrm{I}$. After employing two or three years in making more careful and thorough surveys, and in preparatory work, the real difficulties of the undertaking began to be understood. 
It must be remembered that everything had to be created, at an enormous expense and very slowly, in a country entirely lacking in natural resources, and situated at a great distance from the source of supplies.

It must be recalled, also, that there had been great want of foresight, in proportion to the importance of the work, and this explains the grave consequences which ensued. Notwithstanding the existence of the Panama Railroad along the line of the Canal at nearly every portion of it, the first installation was extremely tedious and costly. Finally it was necessary to construct a large number of buildings to house about 15,000 employees and workmen; hospitals, stores and workshops had to be erected. All of this plant and the preparation of the equipment had already cost enormous sums, and required a considerable length of time before the actual excavation of the work could be commenced. These special difficulties everywhere encountered in the Isthmus were inevitable. It was then impossible to find proper workmen in the neighborhood of the work. Considerable effort was necessary to obtain laborers from other countries and bring them to the Isthmus, and, in proportion as the work grew in extent, salaries increased, as well as the cost of everything.

At that time the unhealthfulness of the climate, due, in a large measure, to the excavation and uplifting of the surface of the ground, also interfered with the progress of the work.

To-day, on the Isthmus of Panama the sanitary conditions have much improved because of the opening of the Canal, and also on account of the deep excavations below the surface, and no difficulty whatever is now felt from the climate, while labor is readily obtained from Jamaica.

The construction of an interoceanic canal presented problems extremely difficult of solution, since, by the very nature of things, the indispensable elements for all preliminary investigations were lacking. To definitely solve these problems the results of many years of observation and experience was required. Just this very thing occurred at 


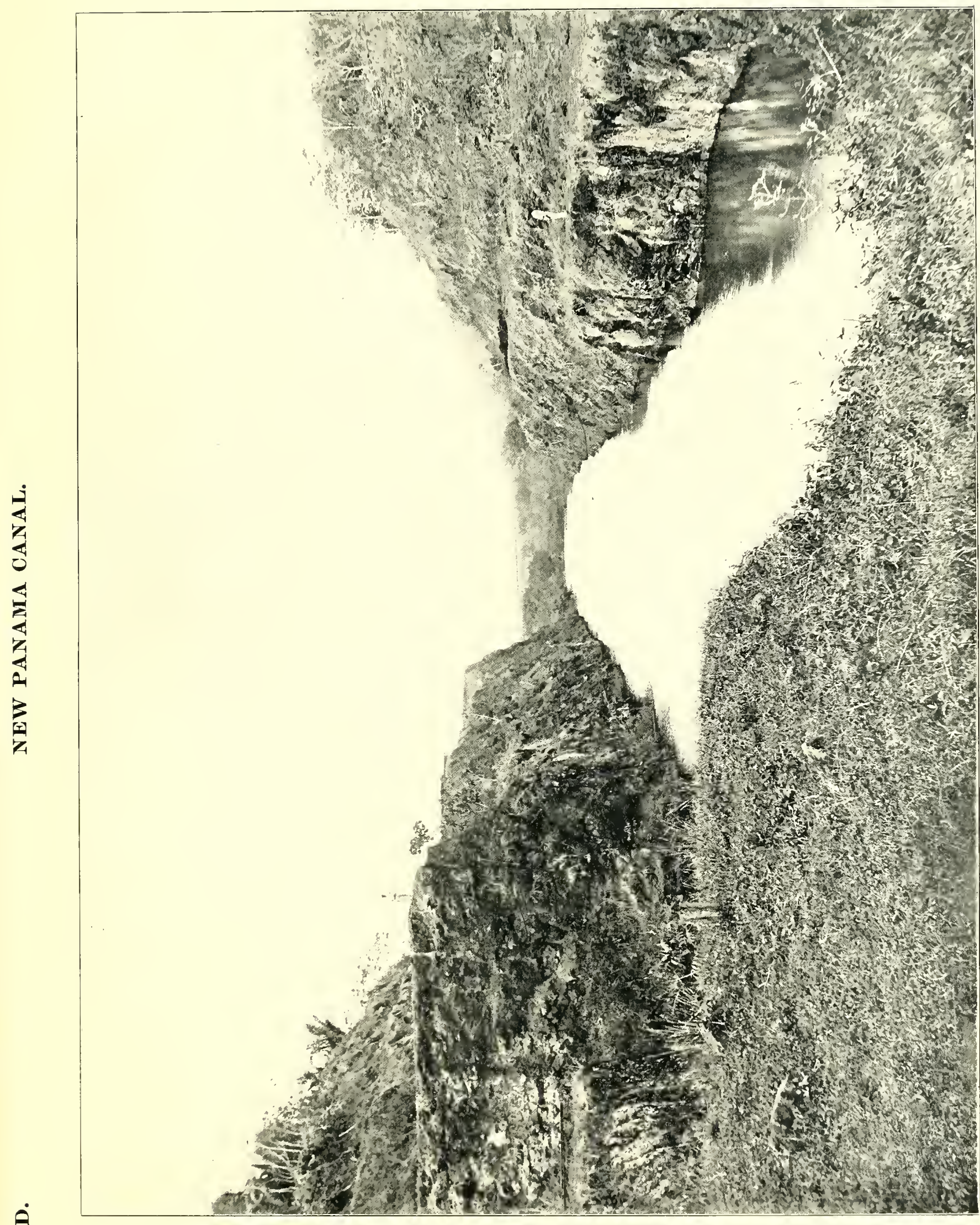




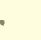


Panama, particularly in the excavation of the large cut at Culebra. The first surveys indicated the mountain to be solid rock, while, on the contrary, a layer of clayey soil was very soon encountered (the crumbling away of which has been greatly exaggerated). At the present time, the excavations of the new Company, which have been carried to a very considerable depth, prove that the entire formation, with the exception of the surface layer, consists of a fairly hard rock of such nature and arrangement that there is no fear of crumbling of the embankment and consequent filling up of the cut, no matter what its depth may be. It is, of course, impossible to enter here into the details of the work done by the old Company. It is sufficient to know that, when the old Company at length decided to build a lock canal, it was financially impossible to do so, because its credit was so greatly impaired that it could not obtain the necessary financial support. In I889, a Receiver was appointed by the French Court and with unlimited powers - particularly to transfer or to assign to any new Company, all or any portion of the Company's assets.

The receipts of the old Company from the sale of its bonds and stock amounted, in round figures, to \$260,000,000.

The items, both of receipt and expenditure, are now a matter of record as a part of the Receivership and may be found on the files of the Court and in the reports of the experts appointed thereon.

These figures are most suggestive. They show, in the first place, that the expenditures actually made upon the Isthmus amounted to $\$ 156,400,000$, and that, of this, the cost of excavation and embankment, proper, amounted to $\$ 88,600,000$. In the second place, the reports show the great importance of expenditures incidental to and connected with the work. No doubt such last-mentioned expenses were to some extent extravagant, but, nevertheless, it must be admitted that, for the most part, they were necessary and will be utilized in the completion of the work by the new Company. 
To properly appreciate these expenses, the plans and profiles must be carefully followed.

The facts just given are deduced from statements made by a special Commission, appointed by the Receiver of the old Company. In all its appraisals and valuations this Commission has evinced extreme discrimination and fairness.

After having made these statements, this Commission desired to determine the actual value of what had been done by the old Company, and upon this point states:

"The enormous amount of material at hand ready to " be utilized, the great number of works established, lands " received and to be received, labor actually expended, ex" perience gained, supplies laid in, preliminaries mapped " out, including the right of way, are worth to the new "Company at least 450,000,000 francs" (\$90,000,000). 


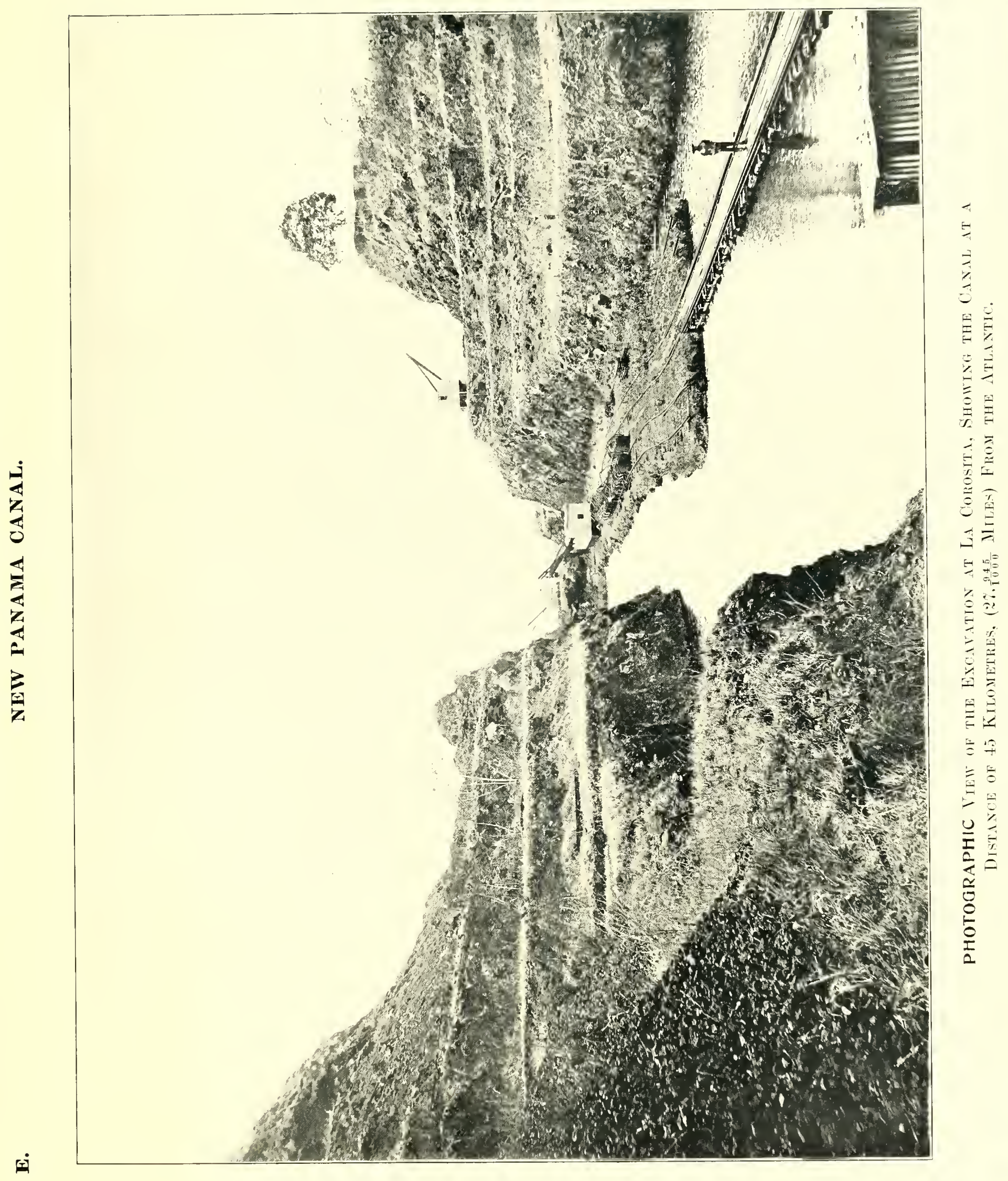




\section{ORGANIZATION OF}

\section{THE NEW PANAMA CANAL COMPANY.}

OCTOBER 20, 1894.

The Receiver asked for and obtained from the Colombian Government two successive extensions of the concession, extending the time for the completion of the Canal to October, I904. (The Government of Colombia has just granted an additional extension of six years more.)

Finally, in 1894, the Court and those having legal charge of the interests of the old Company made an impartial examination of the situation and came to the following conclusions :

FIRST.-That the work actually aocomplished by the old Company in the Isthmus was very large, substantial and avail. able.

SECOND.- That notwithstanding an interregnum of four years, the work previously accomplished was in a satisfactory condition.

THIRD.- That the locations occupied, and the plant on the Isthmus, had been well cared for by the Receiver, and were sufficient for the continuation and accomplishment of the work without extensive and expensive preparation.

FOURTH.-That the climatic dangers, the difficulties of the undertaking, and the cost necessary for its accomplishment, had been grossly exaggerated.

It was therefore resolved to reorganize the old Com. pany, under new management and new conditions.

On the one hand the work was to be renewed and con. tinued.

On the other hand, to ascertain by investigation and the widest experience, whether the construction of the Canal 
could be completed under reasonable conditions of time and money.

It was in this spirit that the New Panama Canal was organized in October, I894, under the general laws of France. Its constitution and method of operation were rigorously restricted.

From the financial point of view, it was thought advisable that a large number of financial institutions of France should purchase the stock of the new Company, and should be represented in the administration of its affairs by their officers, so as to insure for the new Company the hearty support of these great financial interests, as well as the high character and large experience of the gentlemen composing the Board. The stock was declared by the charter to be non-negotiable until the final technical plans were prepared and adopted. The Company was organized with a cash capital of $65,000,000$ francs, or $\$ 13,000,000$, actually paid in.

Thus were assured to the undertaking the sympathies and support of the financial world. All speculation in the stock of the Company before the adoption of final plans was prevented, as the stock, being non-negotiable until said event, could not be registered and quoted at the Exchange.

The Board of Directors is composed of entirely new and independent members, no one of whom had any official relation to the old Company.

The new Company has been officially recognized by the United States of Colombia, and its titles and concessions have been fully confirmed by that Government.

\section{Operations of the New Company.}

The new Company, according to its charter, carefully considered all plans that could attract the attention of serious-minded and practical men, and carefully compared the advantages and disadvantages of each.

This careful method demanded an exact and complete knowledge of the local conditions and the character of the 


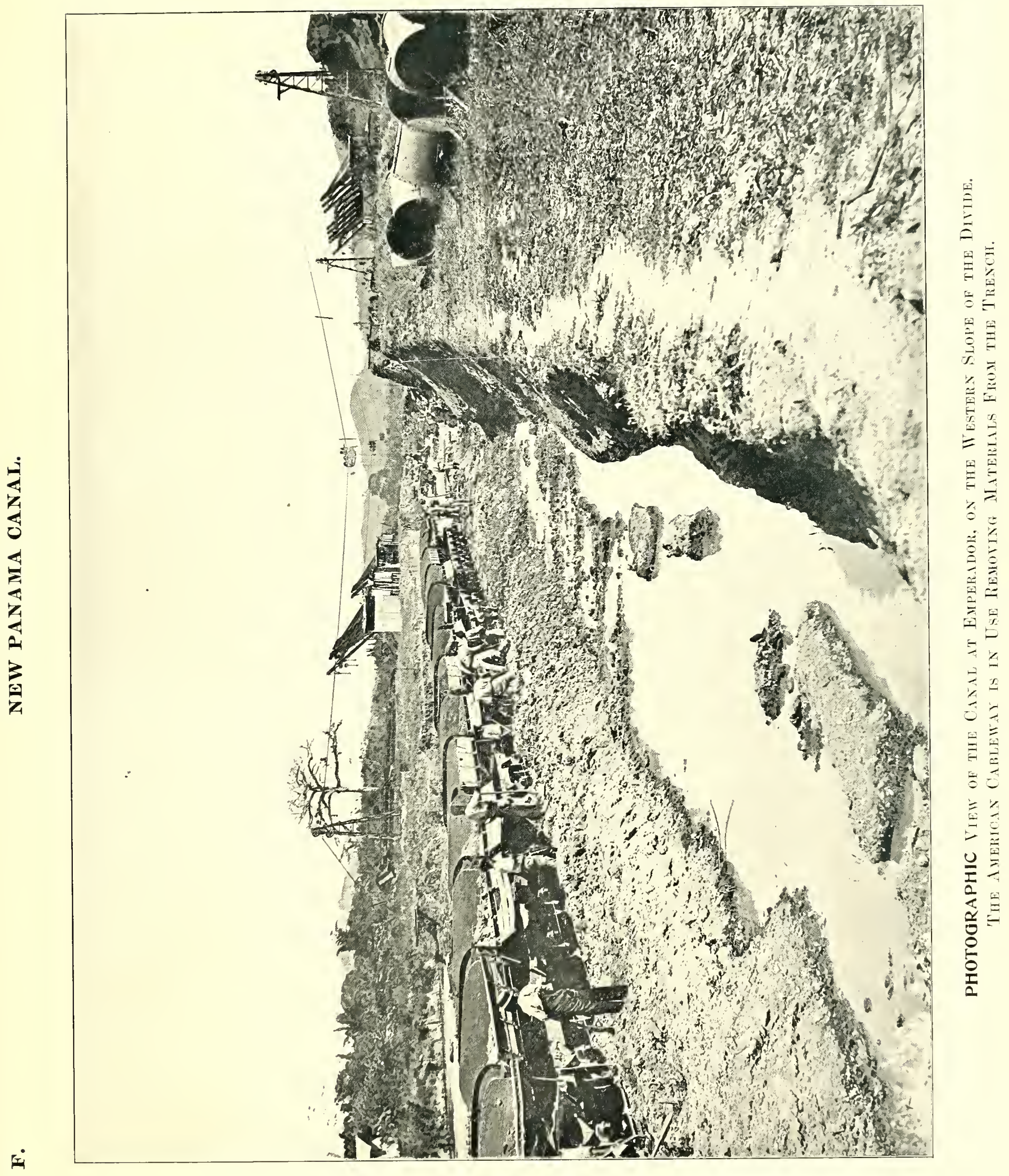


soil where the work was to be carried on, and also full knowledge of the ways and means for its execution; in a word, a thorough knowledge of all the fundamental facts which enter into the undertaking.

The new Company already had the benefit of the results of the preliminary investigations made by the old Company and by the Receiver. It completed these, by carrying on extensive operations upon the work so as to become thoroughly acquainted with the country, while also forwarding the completion of the Canal itself. These operations, long and laborious as they were, accomplished not only the solution of the general problem, but a practical settlement and disposition of numerous lesser problems.

The new Company resolved to carry on the excavations in such an extensive manner that there would remain no hypothetical conditions concerning future work. The work thus carried on for this purpose was also a part of the necessary work on the canal, and therefore forms a portion of the cut of the Canal itself.

The time devoted to these investigations and experi. ences was more than three years, to which must be added the investigations and experiences of the past. But time has not been lost, for it is an infallible principle in large undertakings that, the more detailed and careful the surveys, the surer and quicker the execution of the work. It may also be added that important public works executed too hastily without sufficient preliminary surveys to determine what is necessary to be done and what is impossible, inevitably lead to grave mistakes and delays, if not to disaster.

A great number of plans have been considered, but from the beginning it was resolved not to deviate from the following principles :

FIRST.-That every plan involving any difficulty impossible of execution in the allotted time, and within the limit of expense, should be rejected. 
SECOND. - That in the solution of the technical and detailed problems of the work only those plans should be considered which had the support of experience, and every new idea which might tend to mislead should be rigidly excluded.

THIRD.-That in arriving at the proper solution it was necessary to consider the particular place where the work was to be executed, and also to make due allowance for the influence of the climate of the region. Hence the necessity of undertaking only work not requiring exceptional conditions.

The present Company, after acquiring in October, I894, the Canal works, plant, machinery, concessions, stocks and other assets of every description of the old Company, realized at the outset that the most judicious way to employ its capital was to enter into an entirely new study of the engineering features of the undertaking, and also to begin, on a substantial scale such an amount of work as would set at rest beyond question all doubts as to the quality of materials to be encountered (not only on the surface, but also in the underground strata which it was expected to reach in all the excavations), while at the same time constructing the Canal itself.

The new Company, accordingly, with the aid of the plant at hand and of such new machinery as it was found expedient to purchase, went to work with a force of several thousand men and put in the field a large engineering force. 


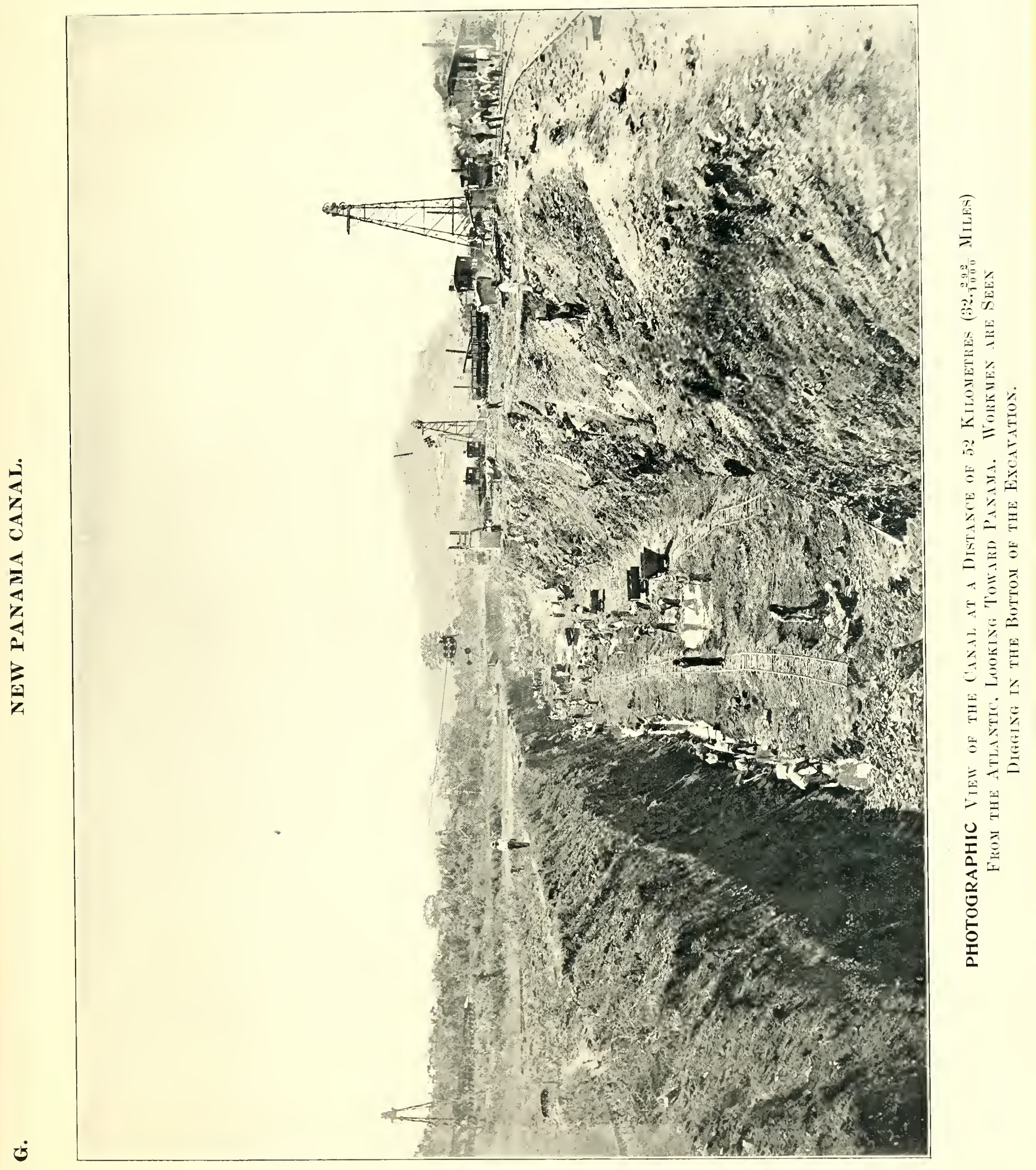




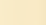




\section{SYNOPSIS}

OF THE PRESENT STATUS OF THE CANAL WORKS AND THE PLAN OF CONSTRUCTION, AS UNANIMOUSLY APPROVED BY THE INTERNATIONAL TECHNICAL COMMISSION.

Line of Route. Two fifths of entire Canal Works now actually completed, and balance under active construction with 4,000 workmen and large force of engineers.

Although the skill of its own Board of Engiueers is worthy of the highest confidence, the New Company, out of abundant caution, and in order to place beyond doubt the final conclusions, caused to be appointed an

INTERNATIONAL TECHNICAL COMMISSION, composed of engineers selected from different nation= alities, a course which assures to the Company the benefit of the widest experience, the severest judgment and most independent conclusions.

The Commission is composed of the most eminent engineers of the United States, France, England, Germany, Russia and Colombia, all of whom have been connected with works of magnitude, and each of whom is distinguished for the highest character and experience. As to all traffic, statistical and economic questions, the new Company also established a Special Commission, presided over by Monsieur Paul Leroy-Beaulieu, the eminent Economist and a member of the Institute of France.

The members of this Commission (whose names appear on a preceding page) are the most distin- 
guished and able men in their profession, and it is self-evident that no one of them would compromise his reputation and honor, acquired through a long life of eminent service, by formulating conclusions upon unfounded, incomplete, superficial or uncertain information, nor such as would fail to stand the severest tests.

This Commission was organized in February, 1896, and besides individual examination, study and correspondence; committee work on special subjects; personal inspection on the Isthmus through a Committee of their number; full discussion and frequent exchange of views; study of all preceding plans and the daily development work upon the Isthmus, this Commission has held over one hundred recorded sessions.

They have also with great care and large expense made most careful observations-continuing over a period of two years-of the Chagres River, for the purpose of ascertaining the various conditions of this river at all times and under all conditions, that they might have definite and reliable data upon which to base their conclusions respecting its treatment.

This eminent Commission of Engineers reached its final and unanimous conclusion on November 16,1898, embodied in the elaborate

\section{REPORT OF THE INTERNATIONAL TECHNICAL COMMISSION,}

which has been adopted by the Company, and under which the work of construction is proceeding. These conclusions, signed by every member of the Commission, establishes the entire feasibility, practicability, and cost of completing the Canal. It is based upon years of continuous study and testing of every element. Different plans, equally practicable, but vary- 


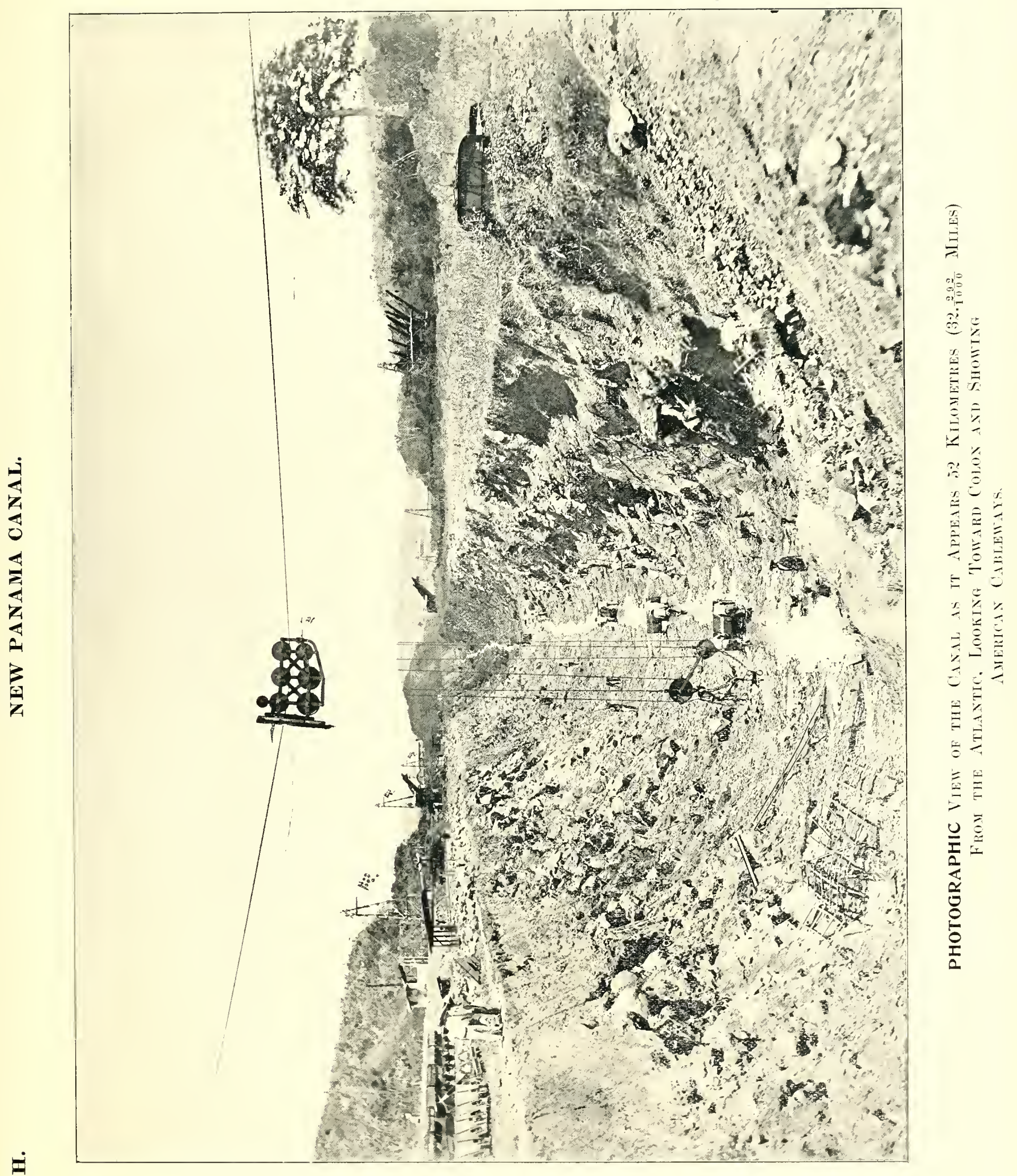


ing in probable cost, have been studied. Many months have been spent in preparing, revising and studying each of them. This work has not been done hastily and superficially. These eminent engineers, chosen especially for their eminence in special departments of engineering work, have studied the questions in all their details-technical, climatic, physical, geologic and economic. Each member rests his reputation on his signature to the Report.

The report of this Commission is probably the most authoritative document ever presented on an engineering subject, prepared by them, as it has been, with the greatest care, after the most thorough and competent investigation and examination, with most exhaustive surveys before them respecting every foot of the ground to be treated, and by the most experienced and eminent engineers of five different nations.

This Report was, on December 2, 1898, delivered by the new Company to the President of the United States for the use of the Government.

The following-described plans are based on said Report :

The Panama Canal extends from Colon, on the Atlantic, to Panama, on the Pacific Ocean.

Its total length is 46.2 miles, including $\mathbf{3 . 3 5}$ miles dredged in the Pacific to deep water.

The great chain of the Cordilleras, which runs along the Isthmus, presents at the point selected a pass which is not too high to preclude the construction of the Canal, while the parts contiguous to both are low.

The profile of the Canal consequently presents, in the central part, a high summit from which the ground slopes gradually (although irregularly) towards the low grounds adjacent to the sea.

Starting from Colon, on the Atlantic Coast, is situate the new city of Christopher Columbus, the location of the works and plant of the Canal Company. From 
the little Port of Folk River we follow the canal for about 11.8 miles. This canal is navigable, varying in depth from 16.4 to 29.5 feet. From the 11.7 to the 26.7 mile, excavation is proceeding the entire distance, and the embankments consequently thrown up gradually rise from the level of the sea to about the height of 49.2 feet, with cuts such as the one of Bohio, which is 131.2 feet in depth, and those of San Pablo and Matachin, which are from 82 to 98.5 feet.

From the 28th mile rises the central mass of earth called the Cordillera. A good deal of work has been done between the 28th and 33d mile. Very near here Culebra is reached, where the labor has been much diminished by the character of the upper layers. The cut begun by the old Company has been continued by the new Company, and now has an average depth of 164 feet.

The slope towards the Pacific 0cean is now reached, and here the declivity of the land becomes great. Work is being carried on the entire distance. The height of the embankment varies from 49 or 65 feet to about 196.5 feet, diminishing at the 40 th mile to from 6.5 to 16.4 feet. From this point to the Pacific the Canal has been completed to the depth of from 6.5 to 26.2 feet. From mile 42.8 to the great depths near Naos, at mile 45.9, the Canal is completed so as to be navigable to a depth of from 16.5 to 29.5 feet, which was recently excavated by the new Company to an average depth of 27.8 feet below the level of the sea.

THE WORK ALREADY DONE CONSTITUTES FULLY TWO-FIFTHS OF THE ENTIRE CANAL WORKS.

The portions of the Canal adjacent to the sea have been excavated; and, although the Chagres River has been for years flowing through them, they can be partially utilized. As to the excavations through the central parts of the profile, they have been made to an extent well illustrated in the accompanying photographs and profile. 


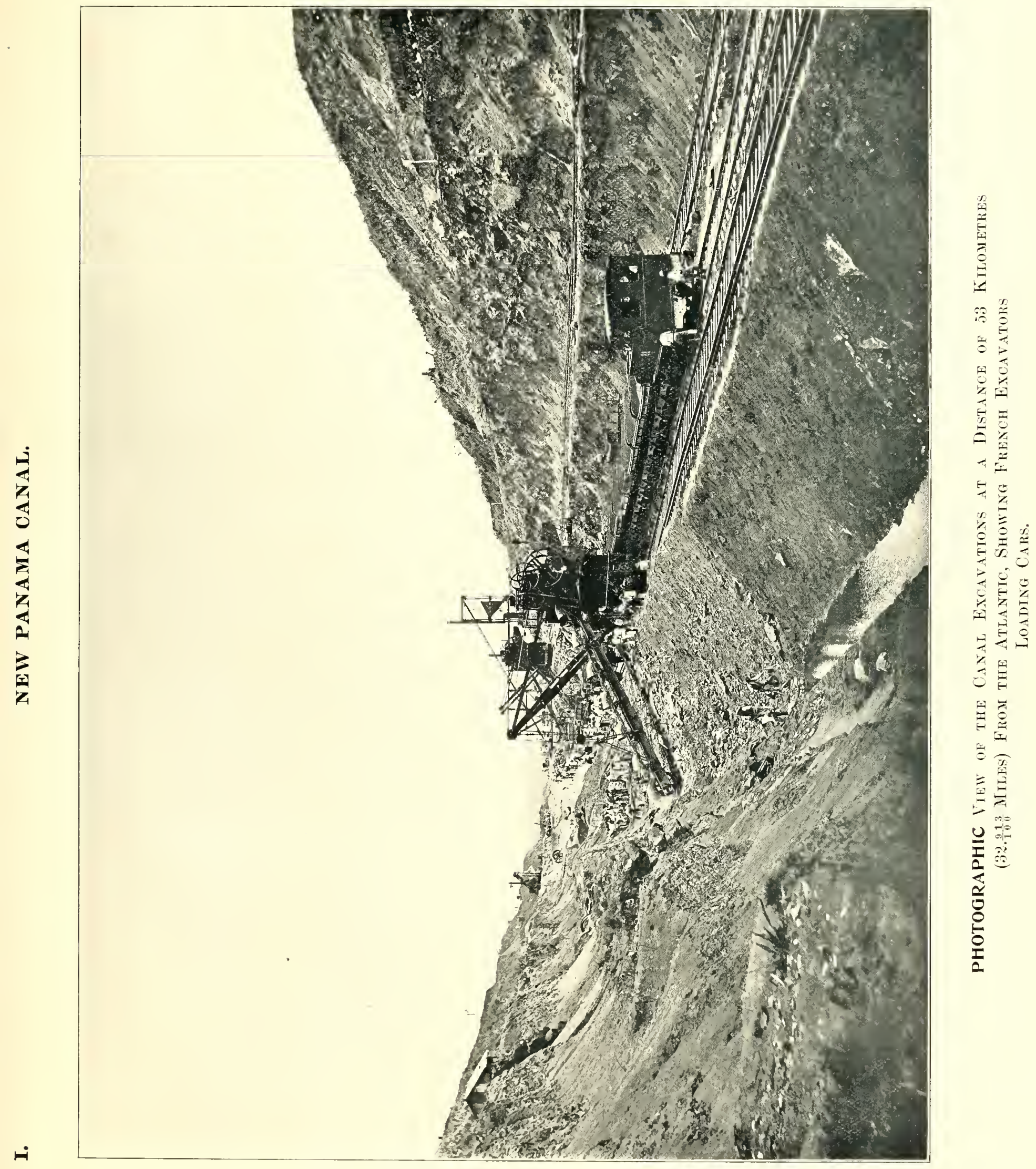



At the present time the topography of all the grounds involved in the project, and the character of the materials to be encountered, are accurately known and delineated; deep and extensive excavations, as well as numerous soundings and borings, have made known the subterranean strata underlying the surface, and by those means no doubt is left as to the soundness of the materials through which the Canal is to be dug to great depths and on which the foundations of the locks, dams and other structures are to be established.

Sixteen different plans have been worked out in detail, including estimates of cost and of time needed for construction.

It is on these complete data furnished by the local engineers and by the observations of its own members on the Isthmus, that the International Technical Commission has based its conclusions, embodied in the plans which will be outlined later herein.

The original purpose of the old Company was to build a canal without locks, freely open from ocean to ocean, but after several years of work, the plan was abandoned, owing to the enormous excavation necessary to cut through the central mass of the mountains (the Culebra) and the difficulty and expense of properly taking care of the occasional torrential flow of the River Chagres.

The alternate plan was to reduce materially the depth of the central excavation, and to establish therein a system of locks, to be fed from the Chagres River. This is the plan adopted by the new Company.

From what precedes, it may be seen that three principal problems presented themselves, $i, e .:$

FIRST.-The determination of the depth to which the central mass must be excavated and of the number and height of the locks to be built.

SECOND.-The designing of the proper methods for the regulation of the flow of the Chagres River.

THIRD.-The feeding of the Canal. 
I.-Depth of Excavation (altitude of the summit level of the Canal bottom).

The number of locks determined by the depth of such excavation (altitude of Canal bottom).

It is obvious that the deeper the excavation, the more time will be required for the work, and the less locks will be needed; also, that too shallow an excavation, while requiring less time, would require more locks.

The necessity of feeding the Canal from the Chagres River, and of providing proper storage for its freshets, are also an element in the determination of the altitude of its bottom level.

This complex problem is obviously capable of several solutions, and before reaching a final decision, the International Technical Commission studied a number of alternate plans, which, after proper consideration, were reduced to three in which the altitucies of the summit level of the Canal are fixed at 29.50 meters (96.78 feet), 20.75 meters (68.08 feet), and 10 meters (32.81 feet), respectively, above mean water in the Atlantic.

Of these three plans, the Commission, after mature deliberation and under the present condition of experience furnished by the work already done, has decided that 20.75 meters ( 68.08 feet) above the sea, with four locks on each slope, as the altitude at which the bottom of the Canal should be placed to make the time necessary for excavation of the balance the most probable time required for the construction of the locks and dams-a result obviously desirable for the proper conduct of the undertaking.

If, however, it be found during the construction of the work that the excavation may require more time, the bottom can be placed at the elevation 96.78 feet (in which case one lock would be added to present plans on each side of the Canal); or if, on the contrary, it be found that the work can be done more expeditiously than expected, the bottom can be placed at the ele- 


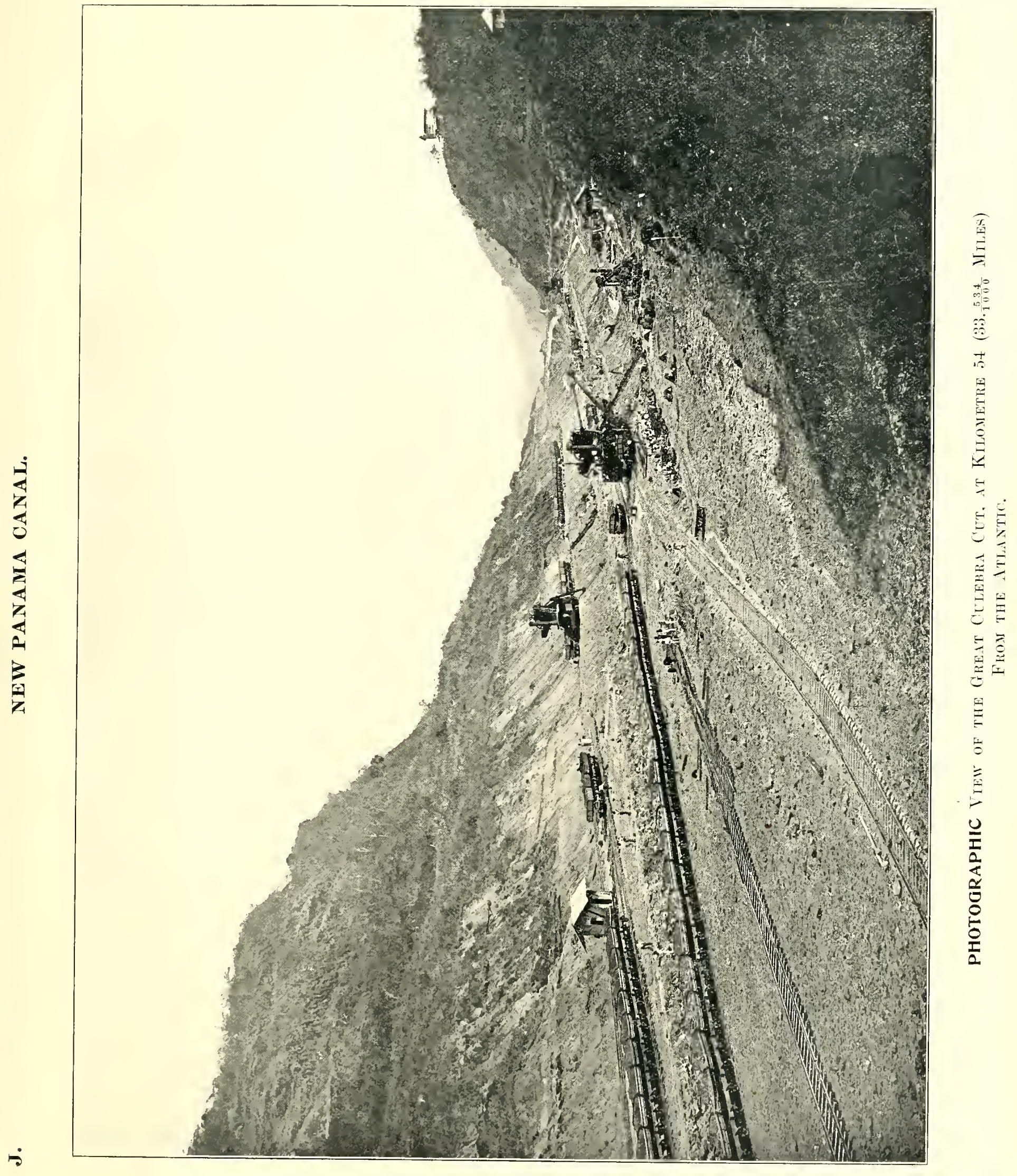



vation 32.81 feet (in which case one lock on each side would be omitted from the present plan); and in either case the change could be done without interfering with the general plan, provided a decision be not too long delayed.

The plan herein described is based on the plan adopted by the International Technical Commission with an altitude of 68.08 feet ( 20.75 meters) above mean sea level.

The summit level, 118.11 feet wide at bottom and 318.35 feet long, is in the deep cut of the Culebra; the upper strata are clayey with easy slopes; below this is a rocky formation, which is to be excavated in wide steps. In the Canal prism a berme is left under water.

The next level, from Obispo to Bohio, with a bottom width of 164 feet, is 13.37 miles long.

At Bohio, another group of two double locks empties into the Atlantic level, which has a width of 98.4 to 111.5 feet on bottom and a length of 14.84 miles.

On the Pacific side, the summit level terminates at Paraiso with one double lock.

The adjacent level from Paraiso to Pedro Miguel is 7,963 feet long, and ends at the latter place with two double locks.

The next level, from Pedro Miguel to Miraflores, is $\mathbf{7 , 9 3 0}$ feet long, and terminates there with one double lock.

The Pacific level, adjacent to the latter, is $\mathbf{4 . 6 9}$ miles long to La Boca, beyond which a channel $\mathbf{3 . 3 6}$ miles long is excavated to deep water.

The depth of water in the locks is to be generally 29.5 feet and is not to exceed 32.8 feet.

All the locks are to be double, the working length being for both 738.22 feet. The width of one of the twin locks is to be 82.02 feet, and the width of the other is 59.05 feet (with an intermediate gate), although, in the opinion of several members of the Com- 
mission, it might be preferable to build both locks of the width of 82.02 feet.

It is designed that the slopes of the Canal, especially in the deep central trench, are to be protected by stone revetments.

The route of the Canal is the same as was originally adopted, and is thought to be judicious, the curves not having less than 9,843 feet radius in the normal course of the Canal, with the exception of one of 8.200 feet.

The curvatures are gentle, not sharp. The smallest radius is 8,200 feet. Of the 46 miles of the Canal 26.75 are straight, and 15 have radii equal to or not exceeding 9,850 feet.

The aim of the Commission has been to resort to simple forms of structures; moreover, it may be seen from its plans that, notwithstanding the magnitude of the work, every part has been kept within the limits of well-established precedents.

II.-Absolute control of the Chagres River by the construction of two great dams which capture and store the floods, supply the summit level with water during the dry season, feed the Canal, furnish abundant hydraulic power transmitted by electricity for operating the locks and lighting the entire length of the Canal by night.

For a considerable part of its length, the location of the Canal is in the valley of the Chagres River, a torrential stream which, although inconsiderable in dry times, is subject to sudden and sometimes enormous freshets; hence the necessity of providing such means as would prevent the destruction of the Canal, unless diverted or regulated by proper means.

Such was the problem which presented itself to the old Company. One of the main causes of the failure of the old Company was evidently the lack of proper preliminary studies for the solution of such an im- 


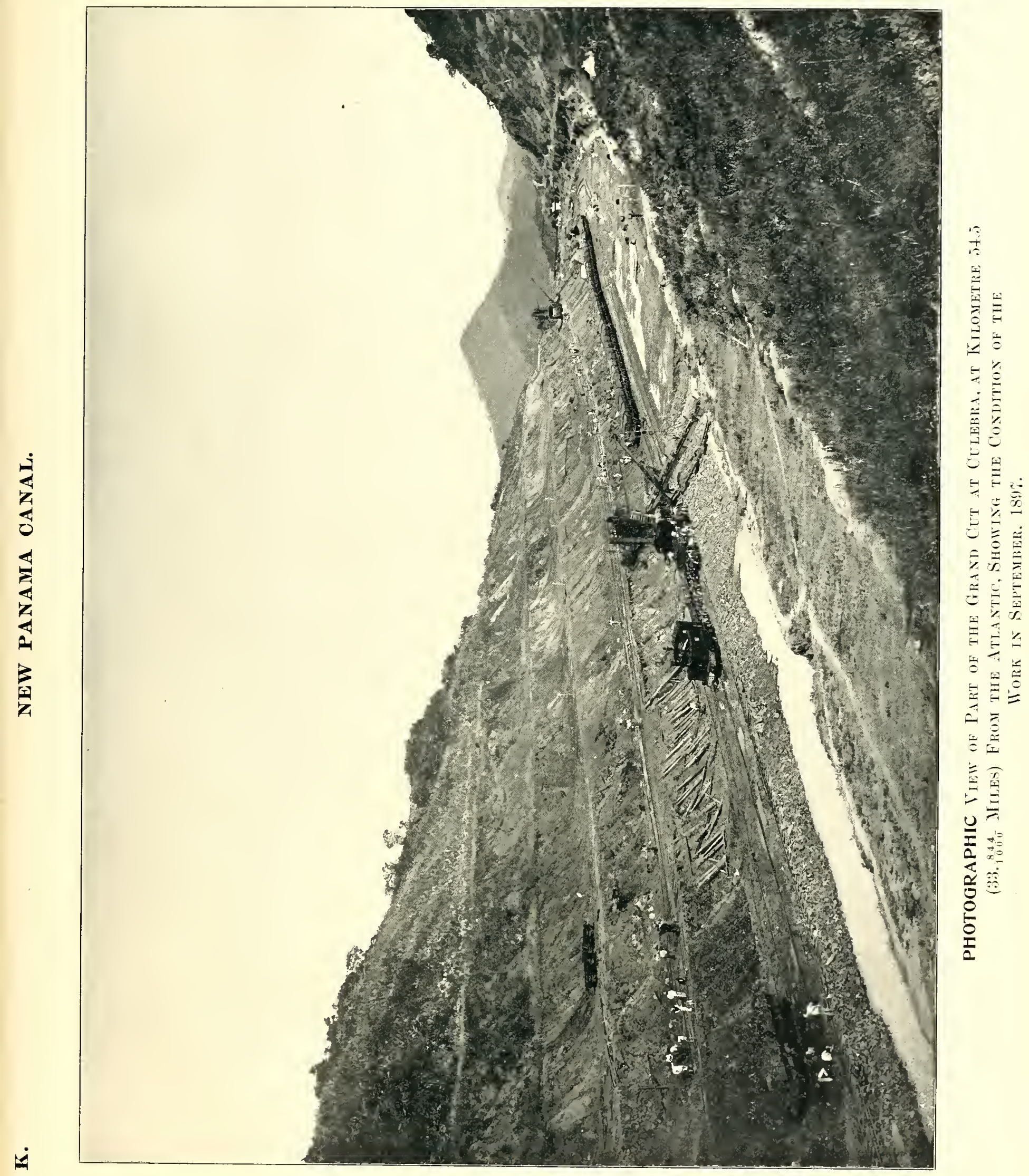


portant problem of engineering, the almost total neglect of the question of the disposal of the Chagres being especially noticeable.

The Receiver of the old Company, fully realizing the deficiency, appointed a Commission of Engineers whose comprehensive report contained useful recommendations, several of which are embodied in the plans now adopted by the new Company.

As it is impossible to admit of the flow of the Chagres River directly into the bed of the Canal, it must be either diverted or so disposed of and regulated as to be harmless in times of freshet.

Diversion having been rejected from the inception of the project as impracticable, or, at any rate, too expensive, it has been decided to regulate the flow by the creation of large artificial lakes sufficiently extensive to store the largest freshets, with proper overflows for the safe disposal of them, without interfering harmfully with the regime of the water in the Canal.

The location, and especially the altitude of the aforesaid lakes, obviously depends, to a large extent, upon the height at which the bottom of the Canal is established, and will be described later; but that presents no difficulty.

In order to properly regulate the flow of the Chagres, two large dams will be erected.

(a) One of these dams will be located at Bohio at the last group of locks on the Atlantic side. It is to be built of earth on a sound argillaceous foundation, and the depth of water against it is not to exceed 65.62 feet.

The maximum height of its water surface is to be 65.62 feet above mean sea level.

This dam will transform the Chagres into a vast lake, the boundaries of which have been accurately established. It will extend a distance of 13 miles to Obispo, where the Canal will leave the river. 
The lake formed by the Bohio Dam will cover an area of 21.5 square miles. Its lowest level is fixed at $\mathbf{5 2 . 5}$ feet, its normal level at 55.75 feet, and its highest level at 65.5 feet above mean tide. It will be revetted with stone, with a foundation bed of clay and abutting against rock banks. The extreme length of crest will be 1,286 feet; the extreme height above the bed of the river will be 75.5 feet, and above the lowest point of the foundation 93.5 feet. All details of construction, including the devices for controlling the river during the progress of the work, have been carefully elaborated. The sites for the two overflow weirs are remote from the dam, and an abundance of excellent material is found near at hand.

The capacity of the Bohio Dam will be from $150,000,000$ to $200,000,000$ cubic meters.

This dam, besides acting as a regulator of the Chagres floods, vill obviate strong currents where the Canal traverses the bed of the river-an extremely important matter for ocean shipping.

(b) The other dam will be located at Alhajuela on the Upper Chagres, about $9 \frac{1}{3}$ miles from the Canal ; will be built entirely of concrete masonry, on a compact rock foundation and abutting against rock walls. It will be about 164 feet above the Canal. The extreme length of crest will be 936.75 feet; the extreme height above the bed of the river will be 134.5 feet, and above the lowest point of the foundation 164 feet.

The cross-sections and the practical details of construction are in accordance with all the requirements of modern engineering. Good rock and sand are abundant in the immediate vicinity.

This dam forms a reservoir covering 10 square miles, with a capacity of from $100,000,000$ to $130,000,000$ cubic meters.

One of the functions of this reservoir (made by the Alhajuela Dam) is that of a feeder to the summit level of the Canal, supplying the summit level with water in the dry season (January-April). But, in addition, 


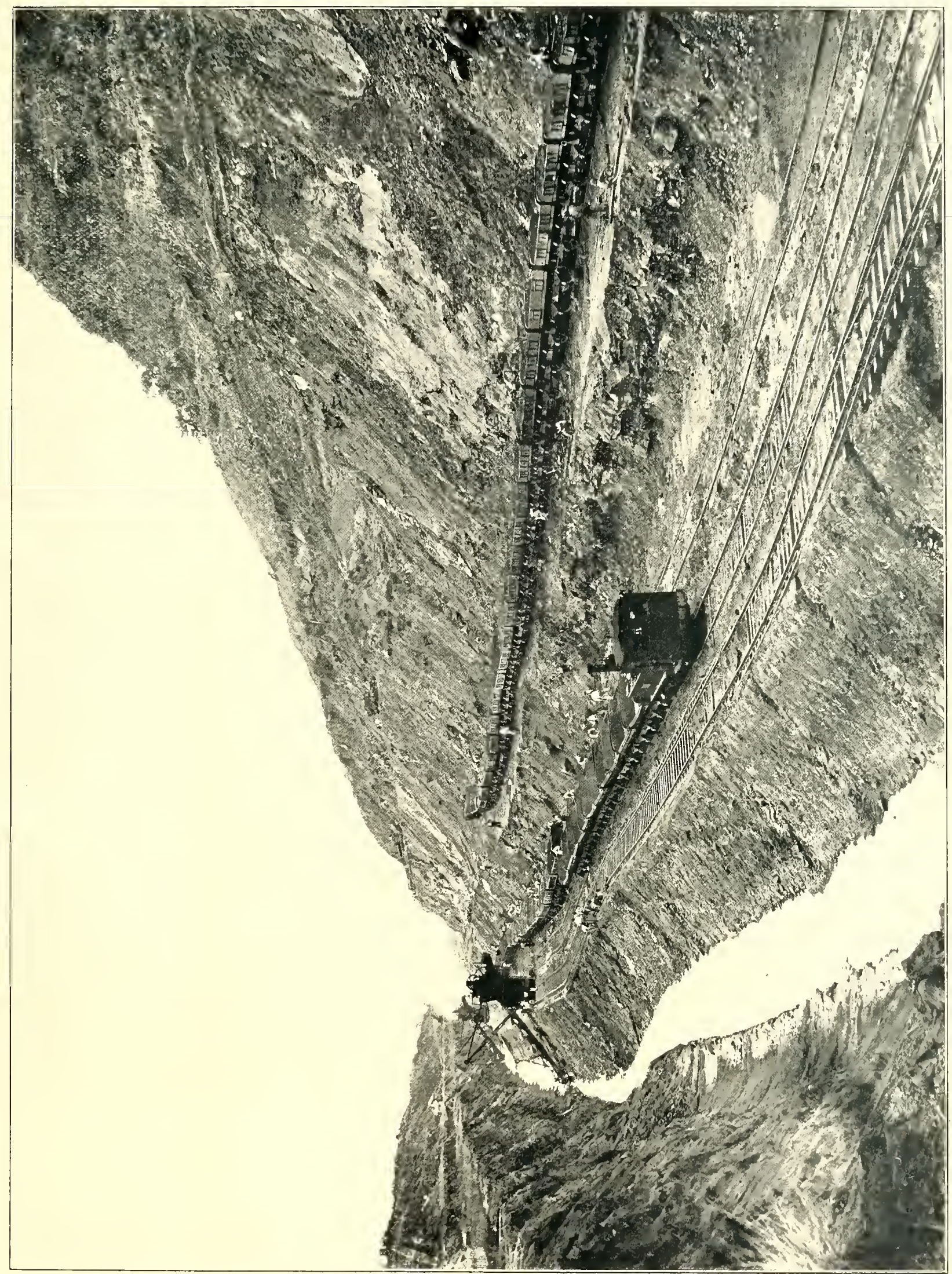


it will assist in effectually controlling the floods of the Chagres and will furnish hydraulic power, transmitted by electricity, for operating the locks and lighting at night the entire Canal from the Atlantic to the Pacific.

(c) For these purposes the reservoir will be connected with the summit level of the Canal by a channel or feeder of a capacity of 25 cubic meters $(6,605$ gallons) per second. This feeder will be built from the Alhajuela Dam to the Canal, a distance of $9 \frac{1}{3}$ miles. It starts at 190.25 feet above sea level and will be built partly on the side hills and partly in inverted siphons or tunnels, and has been shown by exact surveys to be entirely feasible.

It traverses a rough country and its construction will be relatively costly; but when compared with many irrigating canals west of the Mississippi River it offers no serious difficulties.

A short auxiliary railroad will be built along the Chagres River for the construction of the Alhajuela Dam and of its connecting channel.

(d) Both dams can consequently accumulate a storage of at least $250,000,000$ cubic meters $(66,000$,000,000 gallons), which, with proper adjustable weirs, are more than sufficient to control the largest freshets known.

These figures are the result of a careful study of the observations kept since the beginning of the operations of the old Company and of the experience acquired since the building of the Panama Railroad.

Should any larger freshet occur (a very rare occurrence), navigation might be interrupted for a day or two, but, owing to the precautions observed in designing the various structures, the Canal would suffer no damage. 
(e) This entirely disposes of the question of the Chagres. It may flow to any extent which Nature may prompt. It is not only rendered harmless by being securely impounded by the great dams at Bohio and Alhajuela which create the vast Lake and Reservoir described; but, on the other hand (as is well stated by General Abbot in the November Forum), "It may safely be affirmed that the Chagres River is no longer an element of danger, but is rather a useful friend, whose assistance will be of great value to the Canal in its operation."

\section{III.-THE APPREHENSION OF CAVING IN THE DEEP CENTRAL CUT.}

The solution of this question cannot be more tersely nor accurately stated than it has been (in the November, '98, Forum) by the member of the International Commission, the distinguished Brig.-Gen. Henry L. Abbot, who made a special study of the subject :

"The question of caving in the deep central cuthas been studied in the most thorough manner, involving not only many borings and pits. to determine the material to be encountered, but also a cunette excavated throughout the troublesome region along the axis of the Canal, having a projected width at bottom of 32.75 feet, with slopes of about 45 degrees, and a projected elevation above sea level varying from 128 feet to $15 \% .5$ feet. This work, together with a tunnel 689 feet long and 9.75 feet wide, pierced, at an elevation of 134.5 feet above sea-level, at the spot which had given the most trouble on the whole route, combined with the evidence afforded:by the borings and pits at greater depth, leads to the conviction that, at Culebra, where the deepest cutting is required, the excavation has already passed through the strata subject to caving, and that the remainder traverses an indurated argillaceous schist changing to compact rock, where no fears of yielding to pressure need be entertained. At 


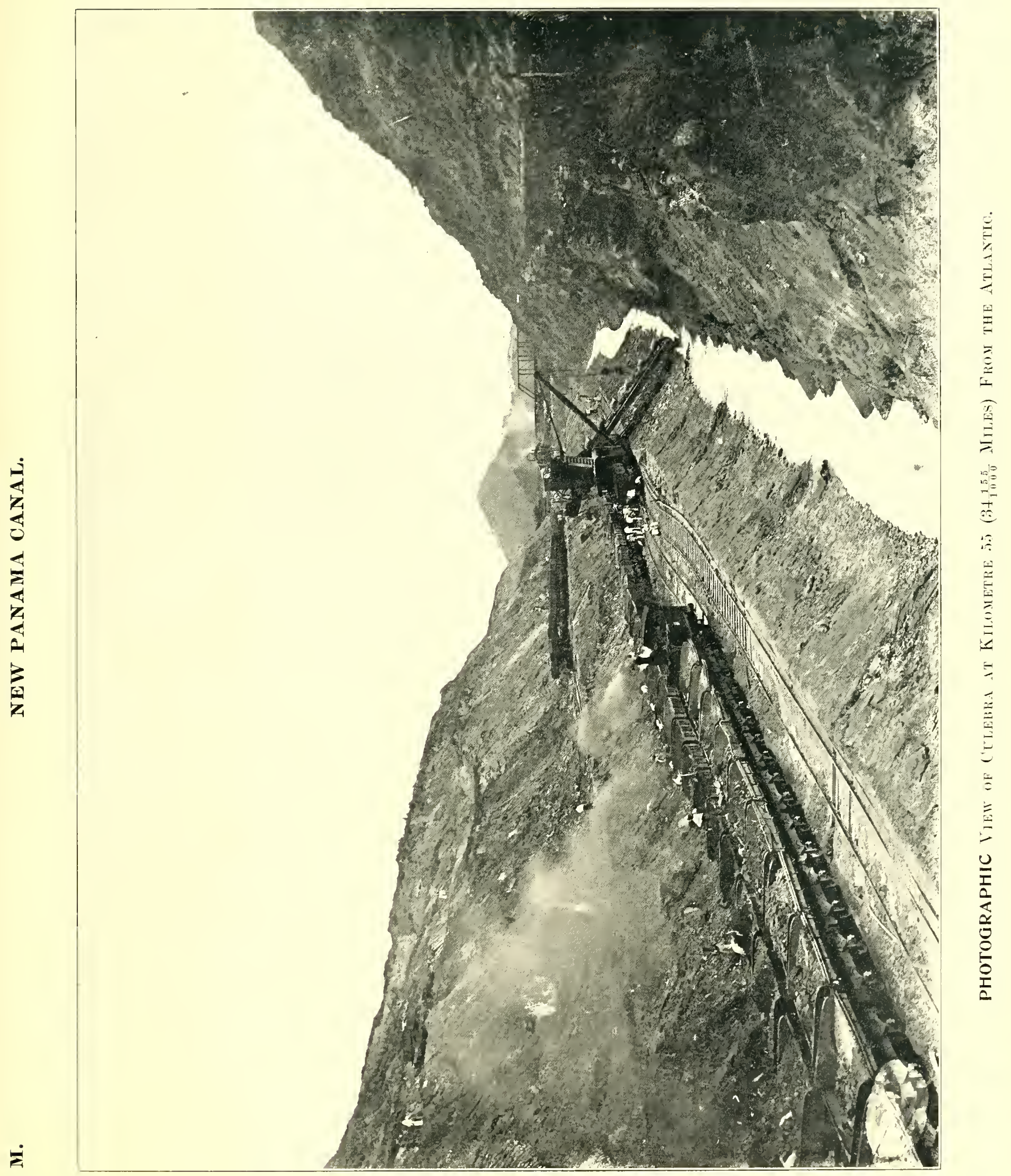



Emperador, where the cutting required for the Canal is much less, the indications are similar, except that the material at present reached is less resisting ; but with proper precautions in the way of drainage, which were wholly neglected by the contractors of the old Company, little or no difficulty from serious caving need be apprehended. This work of experimental excavation has been continued for more than three years, involving the removal of about 3,924,000 cubic yards. It was projected, partly to determine the proper inclination for the side slopes, and partly to estimate the unit cost. The results are highly satisfactory; and the old bugbear of a sliding mountain divide has been proved to be imaginary."

IV.-HEALTH OF EMPLOYEES.

Again we employ the words of General Abbot in the same article :

"The health of the personnel formerly caused trouble, coolies and other races not well suited to hard labor under a tropical sun being employed. With negroes from the British Antilles, little difficulty is now experienced. This matter was carefully investigated during the inspection last spring, American engineers and employees on the Canal and the Panama Railroad being questioned, the fine hospital near Panama-where the Company provides for its sick-being visited, and the views of the medical officers and of the Sisters of Charity, acting as nurses, being obtained. All agreed that the dangers resulting from the climate have been much exaggerated. The surgeon in charge of the hospital, Dr. Lacroisade, who has resided on the Isthmus since 1887, after presenting full statistics covering the sick reports for the past year of a force of about 3,800 agents and laborers under employment, said:

" "Among the diseases attributable to the climate the most numerous are simple marsh fevers, which have not occasioned a single death. Two diseases only belonging to 
the epidemic type have appeared-the beriberi, of which there is no longer any question [it was imported with negro laborers brought from Africa as an experiment, and disap. peared when they were sent back|, and yellow fever. The latter, after having been absent from the Isthmus for at least six years, was imported in 1897 , and continued about six months, from March to August, when it again disappeared after very light ravages (only six deaths). Thus it cannot be considered that this pest is really epidemic on the Isthmus. From the other infectious epidemics, such as variola, typhoid fever, diphtheria, etc., the Isthmus appears to be almost entirely exempt. From the foregoing we may conclude that life on the Isthmus scarcely incurs more dangers than elsewhere, even for Europeans who, after the blacks of the British Antilles, appear to resist the climate best. Residence here would, then, offer nothing alarming, were it not for a constant feeling of fatigue and uneasiness due to a temperature always high, and an atmosphere saturated with moisture.'

"There appears, therefore, to be no danger of serious mortality in the construction of the Canal, if due care be taken to benefit by past experience in selecting the laborers."

V.-HARBORS AT TERMINI-COLON AND PANAMA.

These harbors are so well known to the commerce of the world employing the Panama Route that no extended remarks need be made.

They are natural, not artificial, harbors; good and easy of access.

The ships of many European, South and Central American nations, as well as of the United States, have for over fifty years regularly and daily availed of these ports, where the maritime conditions are most satisfactory.

Neither of these harbors require protection or further excavation. They are in excellent condition.

VI.-There are no active volcanoes within $\mathbf{2 0 0}$ miles of the Canal. 


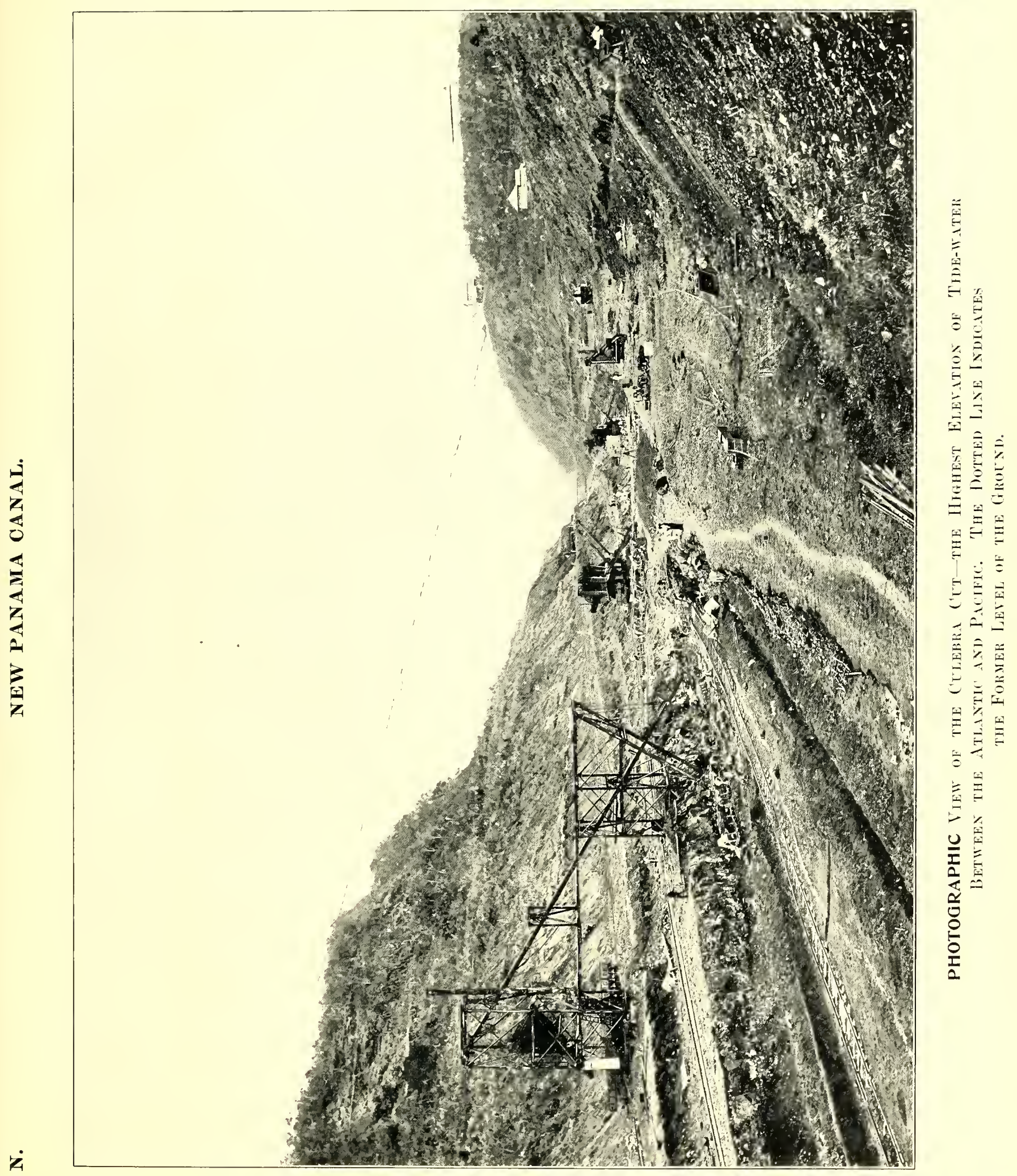



VII.-There are no troublesome winds or river currents to be encountered, even in times of flow.

VIII.-The existence and operation of a railroad (the Panama Railroad), which the line of the Canal closely follows, greatly facilitates the work of construction and is of enormous advantage.

Commerce has employed the Panama Route for over fifty years. The conditions of traffic are established and well known.

The Panama Route constitutes a part of the coast line of the United States, connecting its Atlantic and Pacific coasts. Its terminal cities-Colon, Panamaare ancient and firmly established. Upon the intermediate line thirty railroad stations, serving the neighboring villages and settlements, give character to the route. It is not a marshy jungle. It is a settled country, and the line has been made readily accessible and habitable by fifty years' traffic, development and settlement.

Regular lines of steamers, from Germany, England, France, New York, Belgium, Spain and Italy, on the Atlantic side; and San Francisco and all Central and South American and Mexican ports, on the Pacific side, have for over fifty years regularly employed this route.

The Panama Route, therefore, needs no introduction to the commerce of the world, which has continuously employed it for nearly half a century.

IX.-The time of transit for vessels through the Canal will be less than a day; merchant and war vessels of the largest size can be accommodated.

X.-For four years there have been continuously employed from 3,000 to 4,000 workmen on the Canal works, besides a large force of engineers; and at this moment that number is at work on the Canal. 

long.

XI.-As stated, the Canal will be only 46 miles

Of this, 15 miles on the Atlantic side, and $71 / 2$ miles on the Pacific (about one-half the entire distance), will be at sea-level.

From 12 to 13 miles on the Atlantic side and from 5 to 6 miles on the Pacific side are already completed, and, indeed, are used by the natives.

The intervening higher lands are materially cut.

This constitutes fully two-fifths of the entire work; and the remainder, as before stated, is being completed with a body of four thousand men and a large force of engineers.

XII.-There is nothing in the physical conditions on the Isthmus to prevent a change from a Canal with a system of locks to A SEA LEVEL CANAL, should the latter seem desirable in the future.

XIII.-As above stated, the new Company is now the absolute owner of the Canal, Canal works, buildings, machinery, material, concessions, and all other Canal property on the Isthmus.

The official accounts and reports of experts, on the files of the Court in France, in the Receivership proceedings, show that the expenditures actually made by the old Company upon the Isthmus amounted to $\$ 156,400,000$, and that of this sum, the cost of exca vation and embankment, proper, amounted to $\$ 88$,600,000 .

For the purpose of establishing the actual present and reproductive value of this property a Special Commission was constituted, of which the former Director of the National Academy of Roads and Bridges of France was Chairman. This Commission established the said value at $\$ 90,000,000$, which is a very conservative valuation. Since such valuation, the new Company has made large expenditures for construction, machinery, etc. 


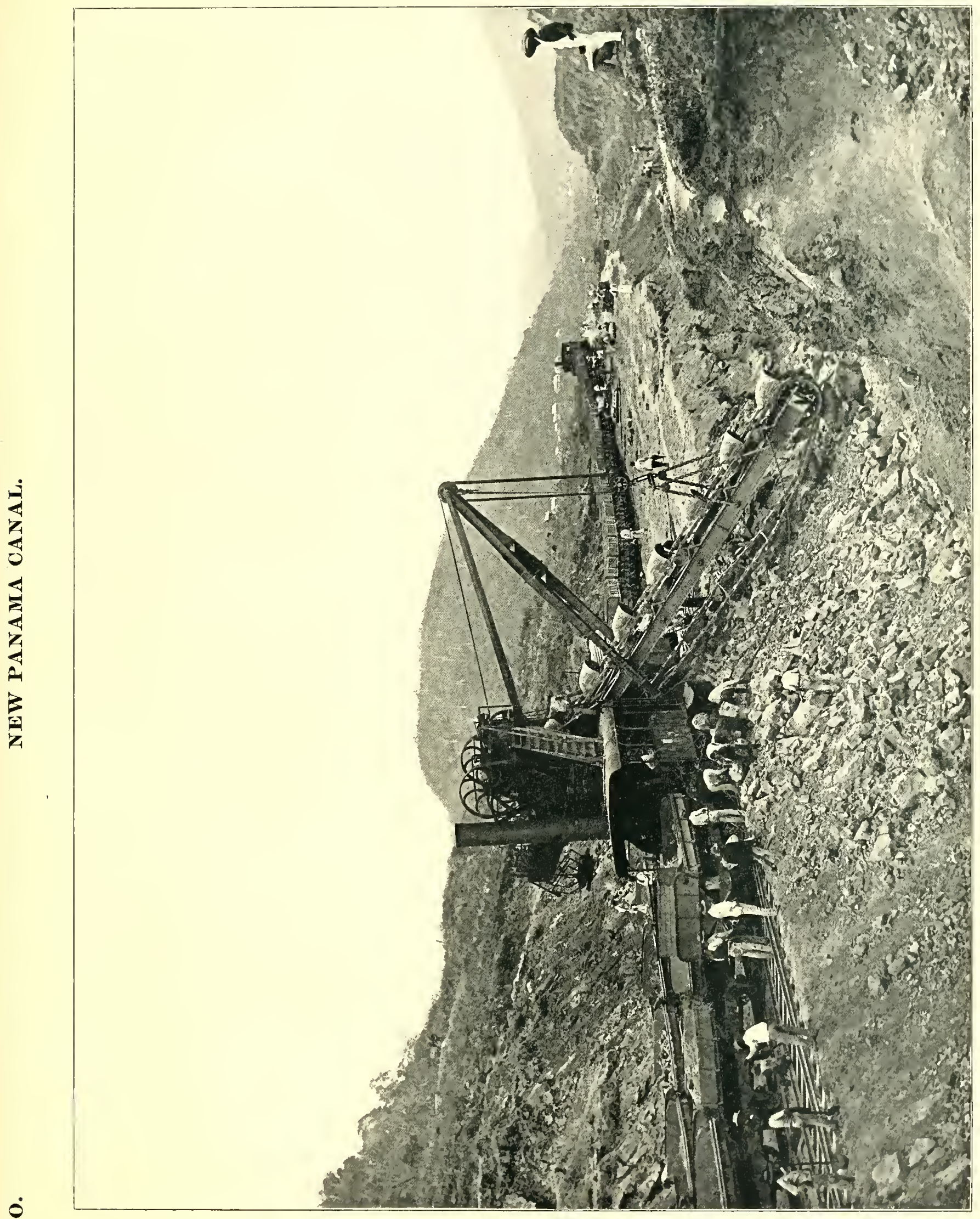

点 
The present fixed assets of the Company exceed $\$ 100,000,000$.

And, in addition, the cash, stocks and personal assets of the Company are some millions more, and ample for its needs.

The Company has no mortgage or bonded indebtedness of any kind. Its property is free from all encumbrance; it has no floating indebtedness, or other debts than monthly pay-rolls, promptly met.

The Company, being financially independent and continuing the construction with its present resources, has neither created a bond issue, nor solicited funds from the public nor from any government.

XIV.-The security-holders of the old Company have no vote, voice, title or ownership in the property of the new Company or in the administration of its affairs. By private contract, merely, the new Company has agreed that after all expenses of operation, maintenance, exploitation, dividends, reserve funds, etc., are provided for, a specified share of the surplus income shall be paid to the Liquidator of the old Company for the benefit of his constituents; but this agreement has no effect upon, or relation to, the absolute ownership and administration of the Canal by the New Company.

XV.--The estimates of cost of completion have been established from the experience acquired during the last four years of actual work on the Isthmus, and is reported by The International Technical Commission, as follows:

The total cost of the work proper under plans adopted .......... \$87,000,000

Add for contingencies........... $15,400,000$

Total............. $\overline{\$ 102,400,000}$

If both locks be built with a width of 82.025 feet, the cost would be increased to ................. $\$ 125,000,000$ 


\section{THE TRAFFIC OF THE PANAMA CANAL.}

To determine the probable traffic of the Interoceanic Canal, many interesting works and numerous publications have beell written in recent years, with widely different conclusions. This is not the place to discuss the different opinions of the writers who have considered this important question, and especially because many of them, either from personal, political or financial motives, have reached conclusions minimizing or exaggerating the amount of traffic, according to their respective interests.

The new Company has carefully analyzed these earlier discussions, and has not been satisfied with the basis upon which they are founded. The Company has sought a basis more reliable than conjecture, and it has pursued an entirely new and more reliable method for the settlement of this question and one not depending solely upon hypothetical conclusions. This method was found. It is based upon the statement of the tonnage of all the vessels that, actually following maritime routes, would find it to their advantage to use that of an interoceanic canal, if the same were open to navigation.

This involved enormous labor, since it was necessary to investigate the traffic of at least 13,000 separate sailing vessels or steamers engaged in ocean navigation or coast wise trade. But the results obtained are most exact. It is sufficient to say that they are very satisfactory and show that the capital invested in the Panama Canal will be amply remunerated.

The delicate and complex questions relative to the determination of the probable traffic of the Canal were examined and acted upon by a Special Committee appointed by the new Company, the President of which Commission is the distinguished and well-known economist, Mr. Paul Leroy-Beaulieu, Member of the Institute of France. 


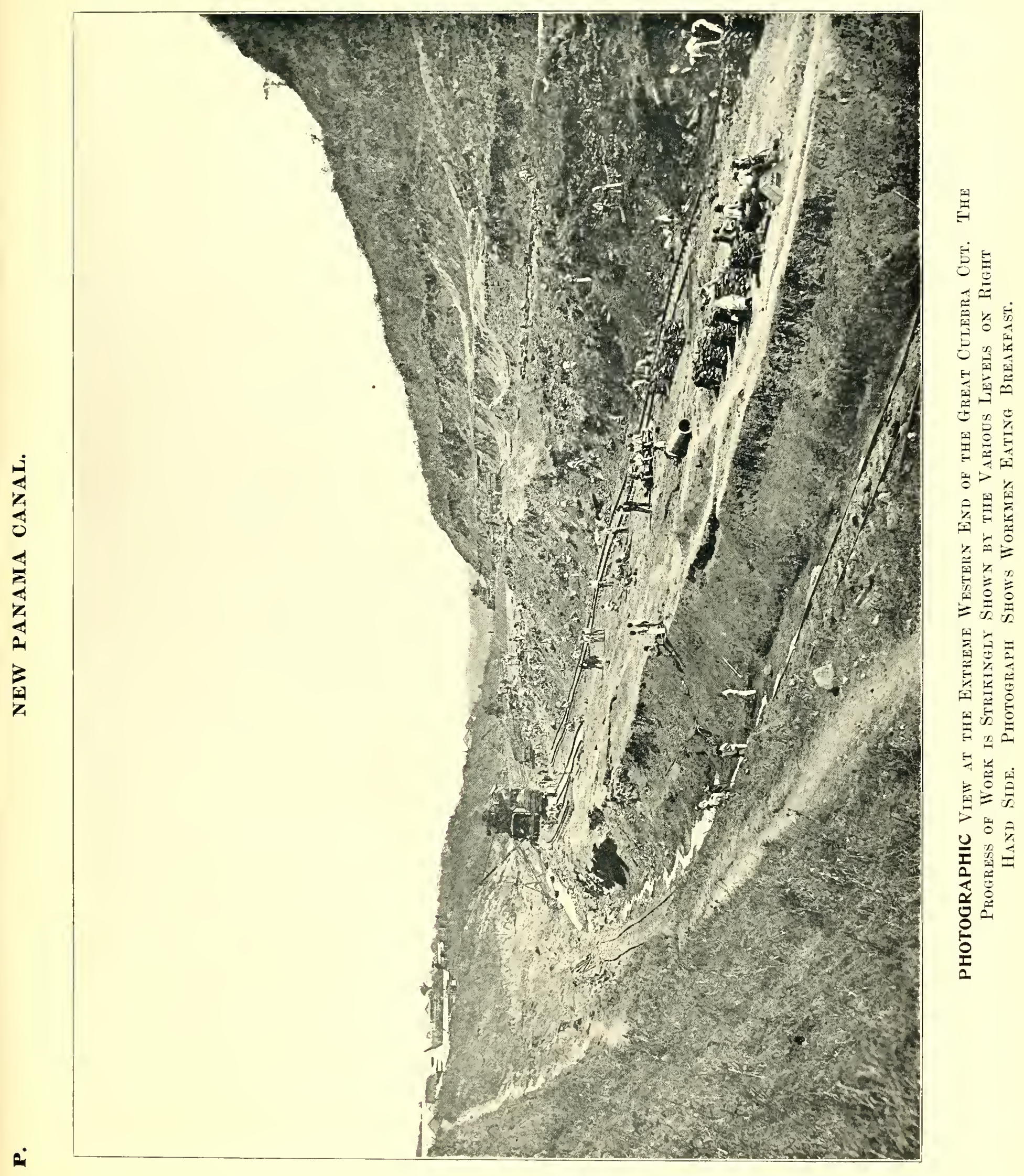




\section{THE CONCESSION TO THE PANAMA CANAL CONPANY.}

The concession of the new Panama Canal Company was granted by the Colombian Government by law dated the 28th of May, 1878, extended by the law of the 26th of December, 1890, and the law of the 4th of August, 1893. The time for the completion of the Canal is thereby fixed at October, 1904; but in this present inonth of December, 1898, the Government of Colombia has granted an additional extension of six years to 1910 , subject to the formality of ratification by Congress when it reconvenes -an assured act. This concession grants to this Company the exclusive privilege of excavation through the Colombian territory and the opening of a maritime Canal between the Atlantic and Pacific oceans-the Canal to be constructed without restrictive conditions of any kind. The concession continues for ninety nine years from the time of the opening of the Canal, either wholly or in part, for public use.

The Government gratuitously cedes to the Company the land necessary for digging the Canal and all its branches.

It also cedes for the purposes of the Canal a zone of land 656 feet in width on each side throughout its entire length, length, wherever it may extend.

In addition, it cedes to the Company 1,235,500 acres of public lands, with all mining rights in whatever localities the Company may choose.

The Company has the right to introduce free of duty or any tax whatever any instruments, machinery, tools, materials, provisions, etc., to be needed for the use and construction of the Canal.

No National tax nor State tax nor tax of any other kind upon the Canal or its dependencies shall be imposed upon the vessels traversing said Canal.

The tolls of the Canal to be charged to all vessels without exception or favor, under similar conditions, is not to exceed 10 
francs (or two dollars) for each cubic meter based on the actual displacement of the hall.

As a compensation for the rights and privileges granted to the Company the Colombian Government is entitled to receive five per cent. on the gross revenue of the Company for the first twenty-five years after the opening of the Canal to the public; from the twenty-sixth year to the fiftieth year it will be entitled to six per cent.; from the fiftieth to the seventy-fifth year seven per cent. and from the seventy-fifth year to the end of the term, eight per cent.

This concession was granted, and the work has been and is carried on, under the protection of the Treaty between New Granada (Colombia) and the United States, made in 1846, and ratified in $\mathrm{I} 848$. The portion of this Treaty which refers to this subject, as well as the particular articles of the Concession relating thereto, is of so much interest that they are quoted in full as follows : 


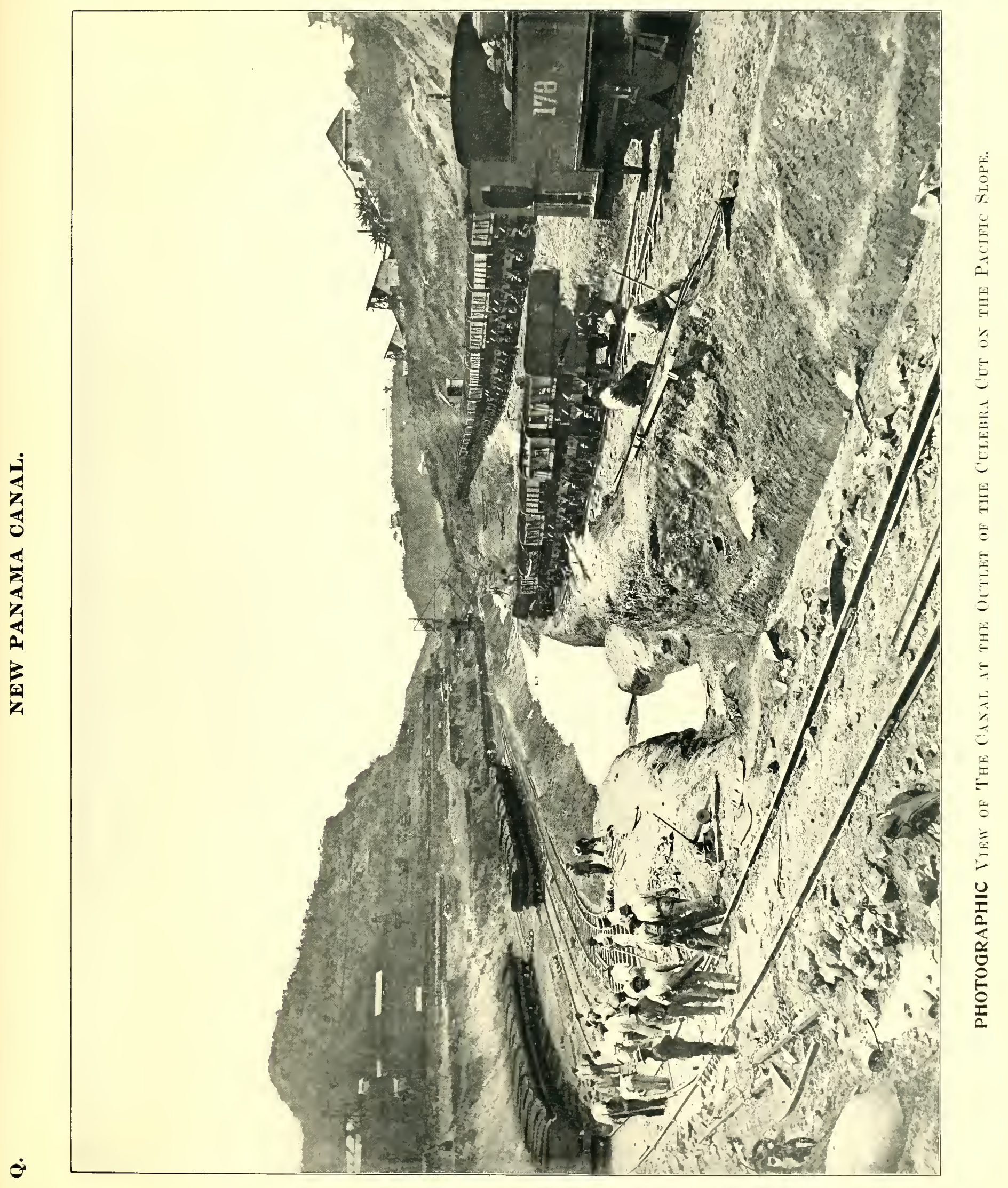




\section{ARTICLE 35 OF THE TREATY OF 1846-8, BETWEEN NEW GRANADA (NOW REPUBLIC OF COLOM- BIA) AND THE UNITED STATES.}

"The United States of America and the Republic of New Granada, desiring to make as durable as possible the relations which are to be established between the two parties by virtue of this Treaty, have declared solemnly and do agree to the following points:

"First.-For the better understanding of the preceding articles, it is and has been stipulated between the high contracting parties that the citizens, vessels and merchandise of the United States shall enjoy in the ports of New Granada, including those of the part of the Granadian territory generally denominated Isthmus of Panama, from its southernmost extremity until the boundary of Costa Rica, all the exemptions, privileges and immunities concerning commerce and navigation which are now or may hereafter be enjoyed by Granadian citizens, their vessels and merchandise; and that this equality of favors shall be made to extend to the passengers, correspondence and merchandise of the United States in their transit across the said territory from one sea to the other.

"The Government of New Granada guarantees to the Government of the United States that the right of way or transit across the Isthmus of Pallama, upon any modes of communication that now exist or that may hereafter be constructed, shall be open and free to the Government and citizens of the United States, and for the transporta. tion of any articles of produce, manufactures, or merchandise, of lawful commerce, belonging to the citizens of the United States; that no other tolls or charges shall be levied or collected upon the citizens of the United States, or their said merchandise, thus passing 
over any road or canal that may be made by the Government of New Granada, or by the authority of the same, that is, under like circumstances, levied upon and collected from the Granadian citizens; that any lawful produce, manufactures or merchandise belonging to the citizens of the United States thus passing from one sea to the other, in either direction, for the purpose of exportation to any other foreign country, shall not be liable to any import duties whatever; or, having paid such duties, they shall be entitled to draw back upon their exportation; nor shall the citizens of the United States be liable to any duties, tolls or charges of any kind to which native citizens are not subjected for thus passing the said Isthmus.

"And, in order to secure to themselves the tranquil and constant enjoyment of these advantages, and as an especial compensation for the said advantages, and for the favors they have acquired by the fourth, fifth and sixth articles of this treaty, the United States guarantee positively and efficaciously to New Granada, by the present stipulation, the perfect neutrality of the before-mentioned Isthmus, with the view that the free transit from the one to the other sea may not be interrupted or embarrassed in any future time while this treaty exists; and in consequence, the United States also guarantee, in the same manner, the rights of sovereignty and property which New Granada has and possesses over the said territory.

$$
\text { * } * * \quad * \quad * \quad *
$$

"Sixth.-Any special or remarkable advantages that one or the other powers may enjoy from the foregoing stipulation are and ought to be always understood in virtue and as in compensation of the obligations they have just contracted, and which had been specified in the first of this article." 


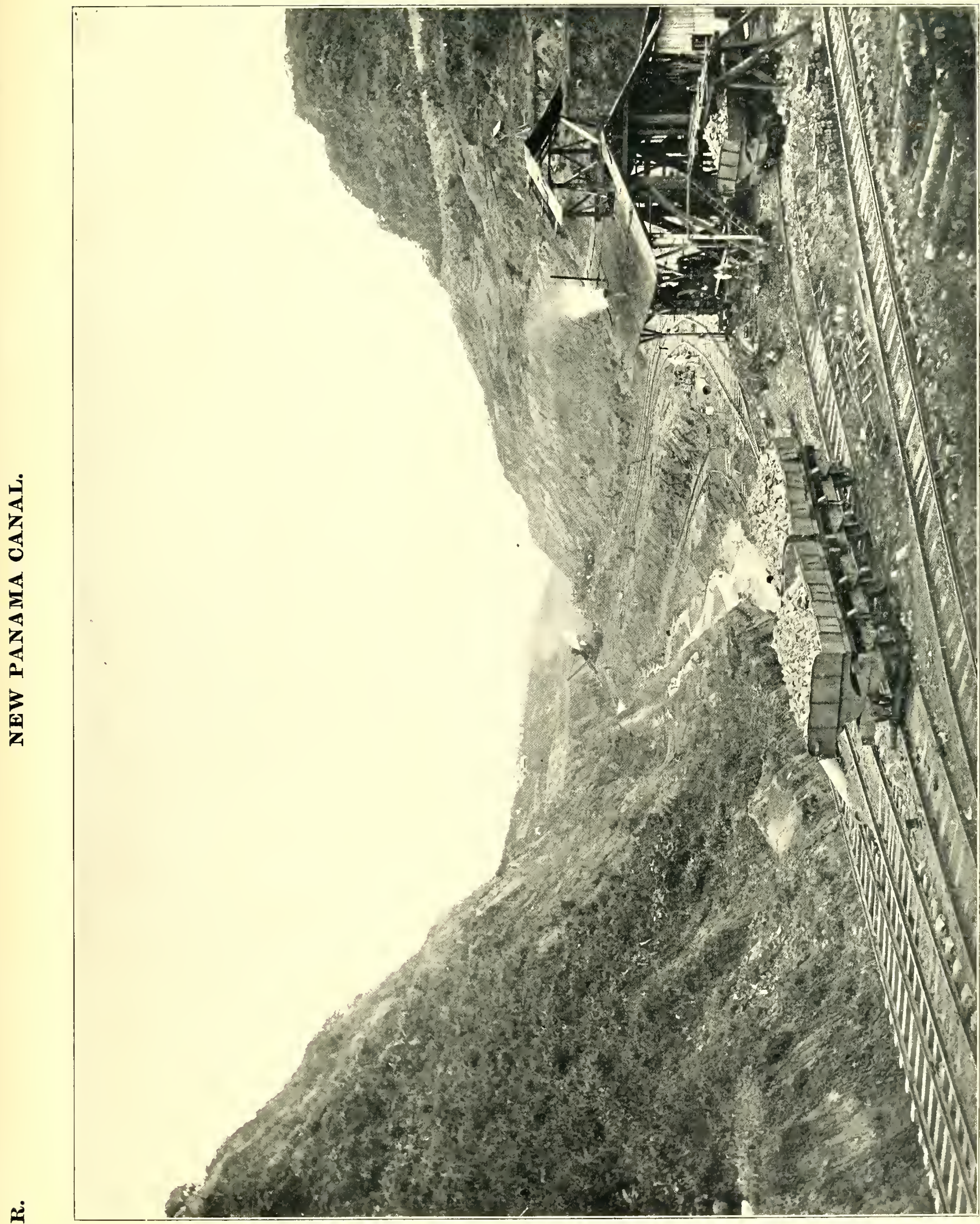

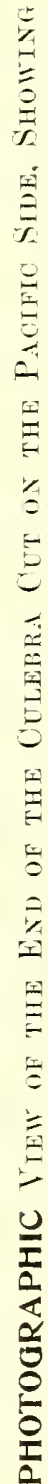





\section{Articles 5 and 6 of the Panama Canal Con- cession of May 18, 1878, under which the Canal is being completed.}

ART. 5. The government of the Republic hereby declares the ports at each end of the Canal, and the waters of the latter from sea to sea, to be neutral for all time; and consequently, in case of war among other nations, the transit through the Canal shall not be interrupted by such event, and the merchant vessels and individuals of all nations of the world may enter said ports and travel on the Canal without being molested or detained.

In general, any vessel may pass freely without any discrimination, exclusion or preference of nationalities or persons, on payment of the dues and the observance of the rules established by the Company for the use of the Canal and its dependencies.

Exception is to be made of foreign troops which shall not have the right to pass without permission from Congress, and of the vessels of nations which, being at war with the United States of Colombia, may not have obtained the right to pass through the Canal at all times by public treaties wherein is guaranteed the sovereignty of Colombia over the Isthmus of Panama, and over the territory whereon the Canal is to be cut, besides the immunity and neutrality of the said Canal, its ports, bays and dependencies and the adjacent seas.

ART. 6. The United States of Colombia reserves to themselves the right to pass their vessels, troops, ammunitions of war at all times and without paying any dues what. ever.

The passage of the Canal is strictly closed to war ves. sels of nations at war with another or other nations, and which may not have acquired, by public treaty with the Colombian Government, the right to pass by the Canal at all times. 
The United States of America is the only Nation with which Colombia has ever made a Treaty wherein is guaranteed to Columbia the neutrality of the Isthmus of Panama and the sovereignty of Colombia over said territory, as above provided; and, therefore, it is the only Nation having the "special or remarkable advantages" provided for by the Treaty.

Under this Treaty, Colombia granted concession to the Panama Railroad, which railroad was thereupon constructed and for forty-three years has been in continuous operation. On several noteworthy occasions the United States has protected the railroad property, in compliance with the obligations of this Treaty.

Also, in contemplation of the provisions of this Treaty, Colombia granted in 1878 the Concession for the Panama Canal now owned by the new Panama Canal Company; and like protection to the Canal, as to the railroad, will, of course, be assured by the United States under this Treaty. Over $\$ 150,000,000$ have been actually invested in the Panama Canal works, two-fifths of the entire Canal work have been completed, and the balance is under active construction, in firm reliance upon the protection assured by the United States under said Treaty to the "Isthmus of Panama from its southernmost extremity until the boundary of Costa Rica." 


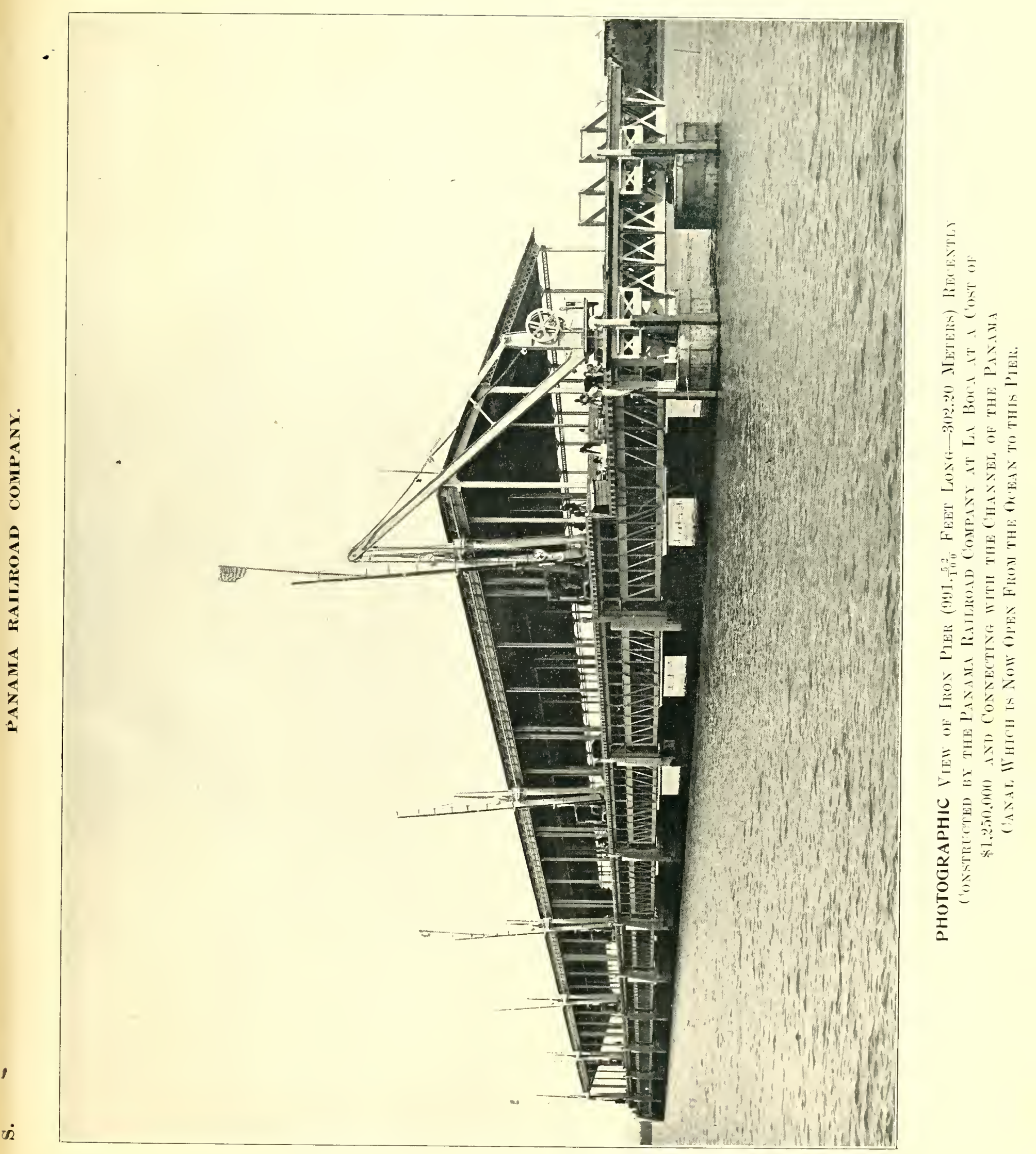





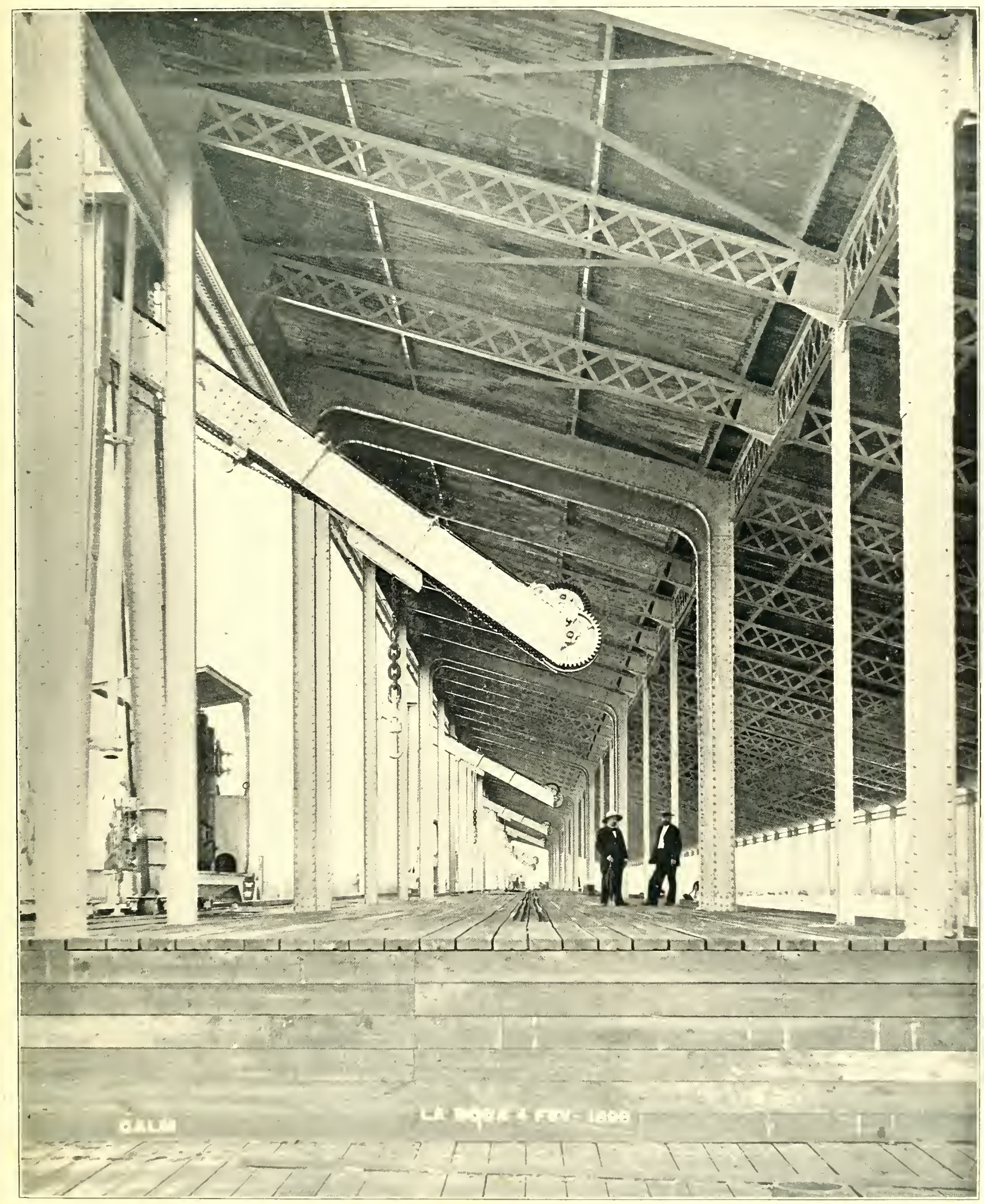

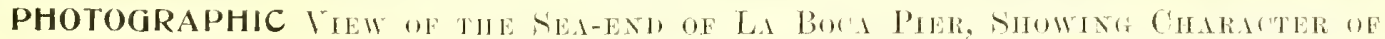

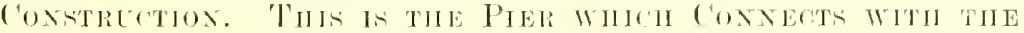



Design of high level dividing Lock System (Bottom Elevation $29.50 \mathrm{~m}$.)

M

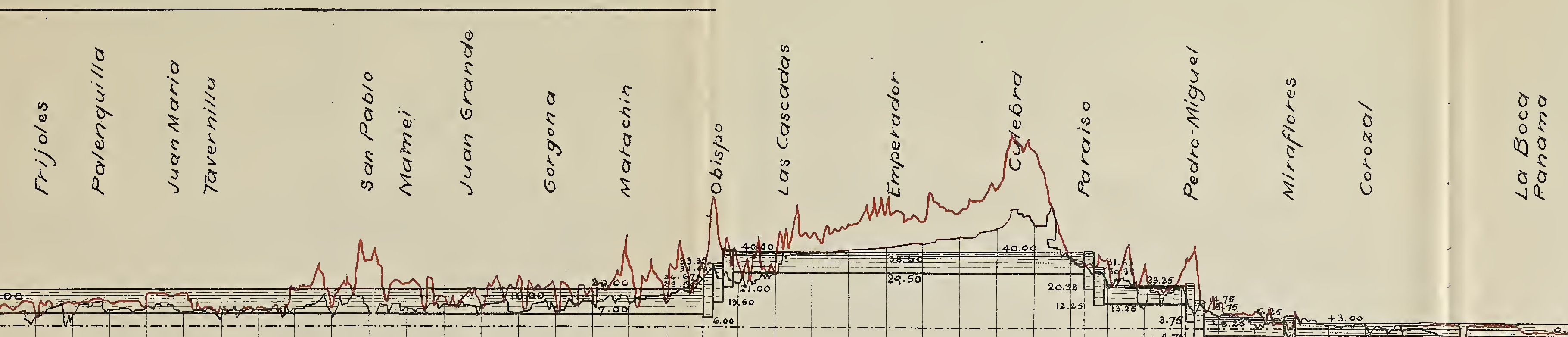

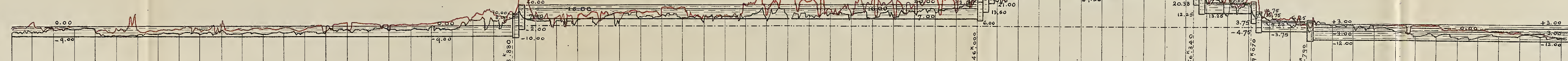
\begin{aligned} \hline 2 \\ \hline\end{aligned}

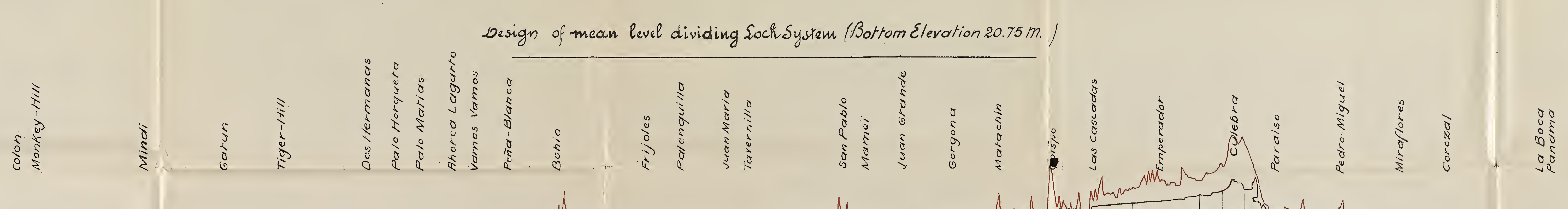

A...

$\mu$

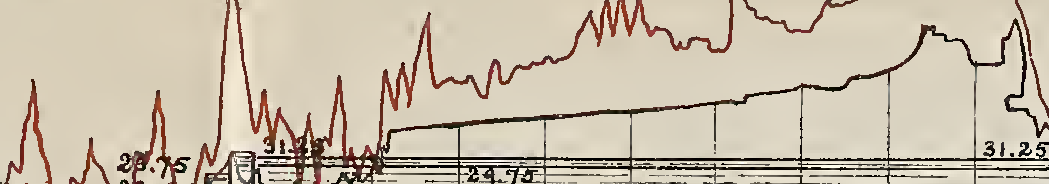

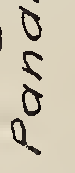

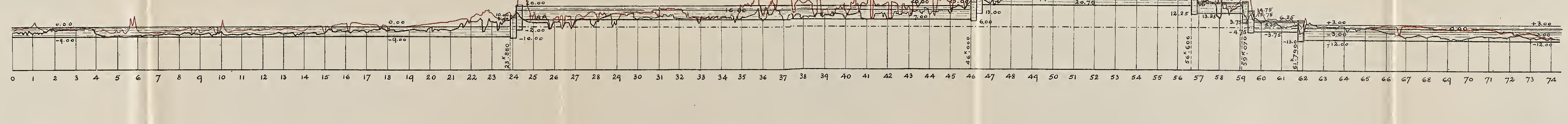

Design of low level diwiding Sock System (Bottom Elevation $9.75 \mathrm{~m}$.

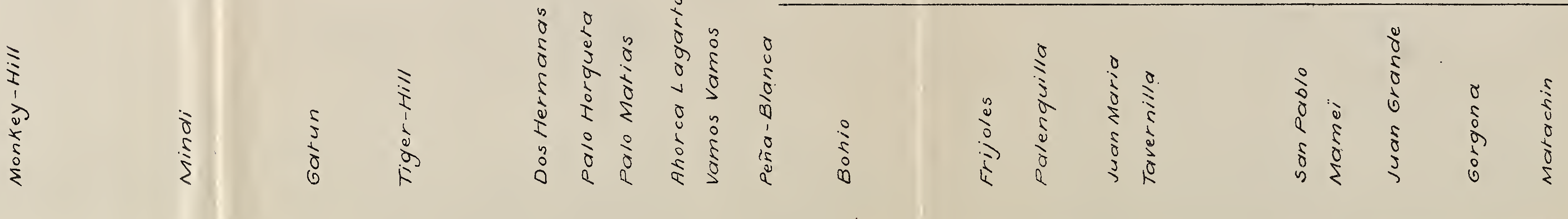

PLAN No 3.

M

A...

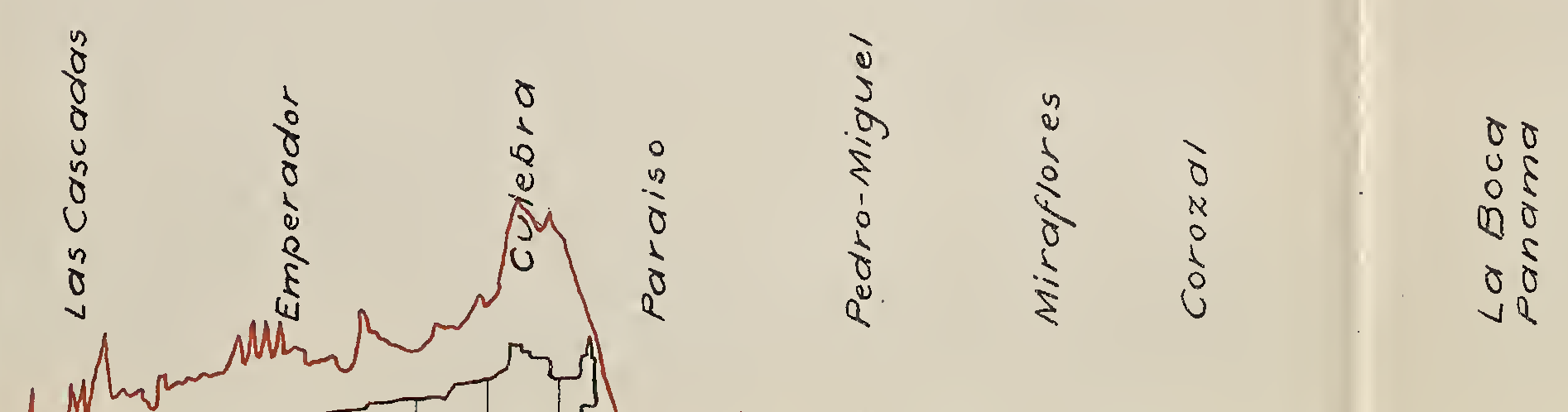



SMITHSONIAN INSTITUTION LIBAARIES

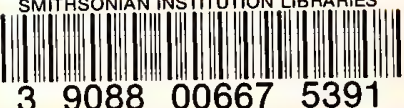

